\title{
UK and EU subsidies and private $R \& D$ investment: Is there input additionality?
}

\author{
Mehmet Ugur \\ University of Greenwich \\ Esref Trushin \\ University of Durham \\ And \\ Edna Solomon \\ University of Greenwich
}

Year: 2015

No: GPERC31

\section{GREENWICH PAPERS IN POLITICAL ECONOMY}




\begin{abstract}
Business research and development (R\&D) expenditures in the UK is low by international standards. To encourage investment, the UK government has been providing both direct and indirect support. The aim of this paper is to address four inter-related and policy-relevant questions: (i) what do we know about the UK regime for direct grant schemes? (ii) is the UK subsidy complementary or substitute for privately-funded R\&D? (iii) does the UK funding regime differ from the EU regime in terms of selection and effect? (iv) does the scope for complementarity/additionality differ between different rates of funding? We address these questions using a rich dataset for more than 44 thousand UK firms from 1998-2012; and a range of treatment-effect estimators with and without control for selection. We report that the EU selection regime is more likely to support firms with long-term R\&D plans. In addition, the UK subsidy is not associated with additionality, but the EU subsidy is. Finally, leverage estimations indicate that targeting a particular rate of subsidy is not likely to make a difference to private R\&D effort in the UK subsidy case; but an increase in EU subsidy intensity does create leverage among firms that fall between the median and $75^{\text {th }}$ percentile of the subsidy intensity distribution.
\end{abstract}

Keywords: Treatment effect, R\&D, innovation, UK

Acknowledgements: Research for this paper has been funded by ESRC under grant reference no $\mathrm{ES} / \mathrm{K} 004824 / 1$. We thank our funders for their generous support. We also thank the participants of two workshops for their helpful comments: (i) Evaluation of R\&D expenditures, firm survival firm growth and employment: UK Evidence workshop, University of Greenwich, 4 June 2015; and (ii) Advances in Business-Related Scientific Research (ABSRC) 14 October 2015, Rome, where the paper was selected as The Best Conference Paper for Excellence in Research. The views expressed here are those of the authors, who are responsible for any errors or omissions.

The paper contains statistical data from ONS which is Crown Copyright. The use of the ONS statistical data in this work does not imply the endorsement of the ONS in relation to the interpretation or analysis of the statistical data. This work uses research datasets which may not exactly reproduce National Statistics aggregates.

Corresponding author: Mehmet Ugur, Professor of Economics and Institutions, University of Greenwich Business School, Park Row, London SE10 9LS.

Email: M.Ugur@gre.ac.uk 


\section{Introduction}

Public support for business R\&D is usually justified on the basis of market failures (Arrow, 1962; 1996). Due to some public good characteristics, knowledge produced by a firm can spillover to other firms and deter the investor from undertaking the optimal level of $R \& D$ investment. In addition, information may be characterized by increasing returns to scale, conducive to very low marginal costs relative to average cost. For welfare maximisation, this property may require free provision of information but poses the serious issue of incentive compatibility in the production of information. Finally, R\&D investment is associated with a high degree of uncertainty - not only with respect to success in generating new knowledge but also with respect to using the new knowledge in the production of new goods and services. For these reasons, governments have devised various schemes to provide direct and indirect support for R\&D investments. The UK government has used such measures with approximately equal intensities, but "the business enterprise component of R\&D expenditure in the UK" has remained low by international standards - "even after adjusting for structural difference between countries." (Hughes and Mina, 2012).

This is not surprising because the case for supporting $R \& D$ activities is not as straightforward as the neoclassical case summarised above. From an evolutionary perspective, knowledge cannot be absorbed unless imitating firms invest in R\&D in the first place (Cohen and Levinthal, 1989). If this is the case, public support may lead to excess investment. Excess R\&D investment can also occur when firms engage in 'patent races', which lead to higherthan-optimum levels of R\&D investment (Dasgupta and Stiglitz, 1980; Dasgupta, 1988; and D'Aspremont and Jacquemin, 1988). Finally, the public good character of R\&D may be overstated. A firm can use a wide range of tools to protect its inventions, including patents and 
secrecy (Nadiri, 1993). Therefore, the case for supporting $R \& D$ activities may be less straightforward than it might appear in the first instance.

These theoretical perspectives imply that direct public support for business R\&D may or may not be effective in inducing firms either to undertake the optimal level of $R \& D$ investment or to create additionality on top of the public subsidy. Because of this ambiguity, a large volume of empirical work has been undertaken to find out how various public support schemes have affected firm behaviour with respect to R\&D effort. A number of reviews of this literature exists. While Hall and Van Reenen (2000) review the literature on indirect support schemes such as tax incentives, David, Hall and Toole (2000) review the literature on direct support schemes. More recently, Cerulli (2010) provides a review of the models and estimators widely used in the empirical literature.

The aim of this study is to add to existing knowledge in three areas. First, we provide evidence on UK firms with a view to bridge the evidence gap on a country that have wellestablished direct and indirect support mechanisms for business R\&D. In 2009, the UK occupied the top $8^{\text {th }}$ place among OECD countries ranked on the basis of direct and indirect support for business R\&D as a percentage of GDP. This is lower than the United States (US) at the $5^{\text {th }}$ place, but above Sweden, Norway and Germany at the $11^{\text {th }}, 13^{\text {th }}$ and $18^{\text {th }}$ places, respectively. Yet, and to the best of our knowledge, there has been no study investigating the consequences of UK support schemes for input additionality. ${ }^{1}$

Secondly, we control for selection in line with the existing literature, but we contribute to existing work by providing novel evidence based on a conditional mean approach that corrects for firm-specific effects in both the selection and outcome models.

Third, we go beyond the current practice and demonstrate how the relationship between subsidy and the R\&D effort differs between firms when the latters are divided into latent classes

\footnotetext{
${ }^{1}$ We have identified only one study - a Department for Business, Innovation and Skills (BIS) analysis paper on output additionality (BIS, 2014). The only study on input additionality was Buxton (1975), based on industry data.
} 
based on subsidy intensity (subsidy/privately-funded R\&D). This ordered-Heckman-type estimation allows for identifying the subsidy intensity levels (classes) where input additionality is relatively more (less) substantial.

To achieve these aims, the paper is organised as follows. Section 2 provides a brief review of the relevant literature, including meta-analysis findings on the balance of evidence in the research field. Section 3 introduces the key elements of the UK and EU funding regimes and the dataset used. The upshot of section 3 is that the rich dataset should be interrogated with appropriate treatment-effect methods that take account of both observable and unobservable factors that affect selection into funding. Hence section 4 is devoted to a discussion of the relevant methods, which are informed by structural modelling of R\&D effort augmented with selection on observables and un-observables. We offer two novelties in section 4: (i) exploiting panel-data techniques to take account of firm-specific fixed effects in both selection and outcome models; and (ii) using an ordered-Heckman estimator to identify the rates of funding at which the scope for additionality is higher (lower). Section 5 provides a range of findings, indicating that the UK regime is not effective in generating additionality whereas the EU regime is. We discuss the difference in the light of observable and unobservable differences between the UK and EU regimes. Finally, section 6 offers a number of conclusions that call for careful policy design and less sanguine assumptions about the case for public support of R\&D investment.

\section{A brief review of the empirical literature}

Following the pioneering work by Blank and Stigler (1957), a large body of empirical work has utilised a variety of datasets and different estimation methods to ascertain whether public and private $\mathrm{R} \& \mathrm{D}$ investments are complements or substitutes. The literature has evolved over 
time, starting with estimations of structural models without control for selection, going through structural models with selection and finally the emergence of matching estimators based on propensity scores (Cerulli, 2010).

David et al. (2000) is an early review of the literature on direct public support schemes and private R\&D effort. Given the time of publication, this review focuses mainly on studies that used structural models without control for selection. Out of 14 firm-level studies reviewed, only 4 used a selection equation or some instrumental variable (IV) estimator. In terms of findings, 3 studies report complementarity (additionality), 5 studies report substitution (crowding-out) effects, and the remaining 6 report mixed/heterogeneous findings driven by differences in the sample or model chosen. The majority of the studies that reported crowdingout effects were based on US firm-level data. The reviewers conjecture that the relative lack of complementarity in the US data may be due to underlying differences between the US and continental European funding regimes.

Later reviews also report mixed findings in the empirical literature. Drawing on a sample of 28 studies that utilize firm-level data, Garcia-Quevedo (2004) reports that 7 studies find additionality, 10 studies find no significant subsidy effects and 11 find crowding-out effects. Dimos and Pugh (2014) is a meta-analysis study based on 52 studies published from 2000-March 2013. With respect to 300 effect-size estimates from 27 studies where additionality and crowding-out effects can be separated, they report that 164 effect-size estimates indicate additionality whilst 136 estimates indicate no effect (117) or crowding out (19). Overall, the balance of evidence remains ambiguous.

However, recent studies that utilise matching tend to report higher incidence of additionality effects. For example, Hall and Maffioli (2008) report strong evidence of additionality in the case of technology development funds in Latin America. Similary, Czatrnitzki and Lopes-Bento (2012) report additionality effect in Flanders, using fourth 
Community Innovation Survey (CIS4) data and matching methodology. Other studies reporting additionality effects include Czarnitzki and Hussinger (2004) and Hussinger (2008) on German firms; Duguet (2004) on French fimrs; and and Aerts and Schmidt (2008) on firms in Germany and Flanders.

These recent studies indicate some clustering of additionality findings around mainly continental European countries. This clustering may indicate some data overlap and dependence between findings. On the other hand, it may also indicate that the funding regimes in these countries are more conducive towards additionality effects compared to other regimes. For example, the early review by David et al. (2000) indicates that R\&D subsidies are less likely to be associated with additionality effects among US firms.

\section{Funding regime and data}

Business expenditure on research and development (BERD) in the UK is relatively low compared to other OECD countries, even after adjusting for inter-country structural differences. Another feature of the UK BERD landscape is that R\&D activity tends to be concentrated in terms of size as well as technology classes (Hughes and Mina, 2012). Direct and indirect public support for business R\&D is around $0.16 \%$ of GDP and this is higher than most other OECD countries, excluding the US, Korea, Canada and France. Whilst the US relies more heavily on direct support, the UK government relies on both direct and indirect support with equal measures (National Audit office, 2013).

Direct public support for business R\&D includes funding from (or originating within) UK government departments, their agencies and non-departmental public bodies (e.g. 
Technology Strategy Board or its successor, Innovate UK). ${ }^{2}$ Given the multiplicity of funding bodies and the change in the rules of the game over time, different selection criteria may have been used during our estimation period from 1998-2012. Nevertheless, it is possible to identify a range of common principles that have remained in place during this period.

The R\&D funding scheme in the UK has to comply with the State-Aid provisions of the European Union. Stated simply, the R\&D grants should not unfairly advantage businesses in one country or unfairly prejudice businesses in other EU countries. This is usually ensured by grading the applications for funding on the basis of a proximity measure that indicate the proximity of the funded activity to the applicant's market operations. According to this market readiness level (MRL) indicators, activities that score $1-2$ are furthest away from the market. They consist of basic research and qualify for public funding of up to $100 \%$. Activities with an MRL score of 3-6 are considered as R\&D activities that are potentially conducive to product and process innovations but may not be undertaken optimally due to spill-over effects or market imperfections. These activities are usually supported through co-funding schemes; and constitute the largest chunk of both UK and EU R\&D subsidies.

Three important differences between the UK and EU regimes should be noted here. First, the R\&D funding decisions of some of the agencies involved in UK funding (e.g., the regional development agencies - RDAs) may have been influenced by both innovation and local development objectives (e.g., job creation and regeneration), which may be incompatible. This is less likely in the EU scheme as regional development aid budget is separate from the budget for R\&D (which falls within the Framework programs and the current Horizon 2020 program). Secondly, the EU funding decision-makers can afford funding applications that are 'closer to market' within the MRL scale of $3-6$. This is because EU funding is usually given

\footnotetext{
${ }^{2}$ The non-departmental public agencies also include eight regional development agencies (RDAs), which also provided R\&D funding between 2000 and 2012 when they were discontinued.
} 
to consortia consisting of multi-county applicants; and as such it is less likely to be constrained by the risk of State-Aid bias. Finally, and for from UK firm's perspective, it is easier and less costly to apply for UK as opposed to EU funding. This is because applications to EU funding is usually through multi-country multi-agent consortia and the areas for funding are usually determined by the funder.

Currently, the largest part of direct funding schemes in the UK are managed by Innovate $U K$ - a public agency that reports to the Department for Business, Innovation and Skills (BIS), but operates at arm's length from the UK Government. It provides funding for business-led projects with the objective of stimulating $R \& D$ and innovation activity, and encouraging the development of innovative products, processes and services with future commercial potential. All business entities (excluding research organisations, charities and public sector organisations) are eligible to apply for funding. Part-funding by the agency depends on firm size and type project, as indicated in Table 1 below.

Table 1: Funding rates as percentage of eligible project costs - Innovate UK 2014

\begin{tabular}{|c|c|c|c|c|}
\hline Applicant firm size & $\begin{array}{l}\text { Fundamental } \\
\text { research }\end{array}$ & $\begin{array}{l}\text { Feasibility } \\
\text { studies }\end{array}$ & $\begin{array}{l}\text { Industrial } \\
\text { research }\end{array}$ & $\begin{array}{l}\text { Experimental } \\
\text { development }\end{array}$ \\
\hline $\begin{array}{l}\text { Micro ( }<10 \text { employees) OR } \\
\text { Small ( }<50 \text { employees })\end{array}$ & $100 \%$ & $70 \%$ & $60 \%$ & $35 \%$ \\
\hline Medium (<250 employees) & $100 \%$ & $60 \%$ & $60 \%$ & $35 \%$ \\
\hline Large (250+ employees) & $100 \%$ & $50 \%$ & $50 \%$ & $25 \%$ \\
\hline
\end{tabular}

Source: https://www.gov.uk/government/organisations/innovate-uk 
Fundamental research is eligible for full project cost funding irrespective of the firm size. It is defined as "theoretical work undertaken primarily to acquire new knowledge ... without any direct practical application or use in view." For all other research types small and mediumsized firms are eligible for somewhat higher funding rates - usually $10 \%$ more of the project cost compared to large firms. Industrial research is funded at a rate of 60 and 50 percent of the project cost for SMEs and large firms, respectively. It is defined as "investigation aimed at the acquisition of new knowledge and skills for developing new products, processes or services or for bringing about a significant improvement in existing products, processes or services." Experimental development research is funded at lower rates $(25 \%-35 \%)$ as it is closer to imitation rather than innovation. Given these rules, firms can apply for part-funding at or below the indicated rates. The agency decides on whether to fund and the amount of part funding, taking into account the project documentation and other information about the applicant.

As far as eligibility and funding rules are concerned, the regime is transparent. However, Innovate UK does not publish information about how they set funding priorities with the exception of references to policy documents published by BIS. In addition, the Business Research and Development Database (BERD) provides information on UK government funding received, but does not provide information on successful and unsuccessful applications. Another area where public information is lacking concerns implementation monitoring. There may be an accounting-based audit process, but we do not know how Innovate $U K$ ensures that part-funding is spent in accordance with project objectives. Nor do we know if funding recipients are graded in terms of compliance with the conditions of the part-funding or on the basis of some performance indicators over the project life.

In this study, we use data from BERD - a repeated annual survey designed to measure R\&D expenditure and employment in UK businesses. Throughout the estimation period (19982012), the BERD survey has been based on a random sample stratified by product group and 
employment size-bands. The sample itself is drawn from a sampling frame that consists of all firms known to be $R \& D$-active through information from HMRC R\&D Tax credit claimants, other sources of administrative data, community innovation surveys (CIS) and responses to a survey question about R\&D activity in the Annual Business Survey (ABS). As of 2011, the sampling frame consisted of 25, 511 firms.

The stratified sample consists of about 400 large firms that account for about $80 \%$ of UK business R\&D expenditures (sampled 1:1); size-band2-firms (100-399 employees) sampled 1:5 and size-band3-firms (0-99 employees) sampled approximately at a rate of 1:20. The largest 400 firms receive a long survey form, with detailed questions on R\&D types (e.g., total, intramural, extramural, current, capital, basic, applied R\&D) and sources of funding (e.g., privately-funded $R \& D$, and public R\&D support received from the UK government and the European Commission separately). Other firms receive a short survey form with questions on total, intramural and extramural R\&D only. Despite the difference between the question sets, BERD reports detailed breakdown of $R \& D$ types, employment of $R \& D$ personnel and other related data for all firms. Missing data for smaller firms is imputed from third-party sources or estimated by the Office of National Statistics (ONS). (See ONS, 2012).

The elaboration on the funding regime and the data sources above indicates that the selection into UK and EU funding regimes is subject to both observable and unobservable factors. On the one hand, we can observe and verify the extent to which both UK and EU funding decisions are related to firm size, firm's R\&D capacity (e.g., R\&D personnel and investment in R\&D-related capital), industry characteristics, engagement in civil/defence $\mathrm{R} \& \mathrm{D}$, etc. However, other criteria used in the funding decision are not observable in the data - e.g., project quality, MRL score, composition of applicants, etc. The implication is that the selection model for analysis should be suitable for taking into account the effect of both observable and unobservable factors (see below). 
Table 2 above indicates the UK support intensity (direct UK government funding as percentage of total business R\&D expenditures) is around 7\%, with a range from about $10 \%$ in 1998 to $7 \%$ in 2012. The table also indicates that UK support intensity during the crisis years of 20092011 remained about 1.5 percentage points higher than the level in 2008 . Finally, the number of firms in BERD has increased steadily over the years - from about 8.5 thousand in 1998 to 22.2 thousand in 2012 . The panel over the analysis period is unbalanced and consists of 44,497 unique enterprises (firms).

Table 2: Total R\&D expenditures and UK subsidies: 1998-2012 ( $€$ mn.)

\begin{tabular}{|c|c|c|c|c|}
\hline Year & $\begin{array}{c}\text { Number of } \\
\text { firms } \\
\text { (enterprises) } \\
\end{array}$ & $\begin{array}{l}\text { Total R\&D } \\
\text { ( } € \text { mn.) }\end{array}$ & $\begin{array}{c}\text { Central- } \\
\text { government-funded } \\
\text { R\&D ( } € \text { mn.) }\end{array}$ & $\begin{array}{c}\text { Support } \\
\text { intensity } \\
(\%)\end{array}$ \\
\hline 1998 & 8,350 & 10900 & 1049 & 9.62 \\
\hline 1999 & 7,678 & 11600 & 1133 & 9.77 \\
\hline 2000 & 8,630 & 11800 & 951 & 8.06 \\
\hline 2001 & 8,656 & 12200 & 743 & 6.09 \\
\hline 2002 & 10,930 & 12900 & 806 & 6.24 \\
\hline 2003 & 8,926 & 11900 & 976 & 8.20 \\
\hline 2004 & 11,752 & 14500 & 1312 & 9.05 \\
\hline 2005 & 12,969 & 15600 & 1125 & 7.21 \\
\hline 2006 & 16,849 & 16600 & 1042 & 6.28 \\
\hline 2007 & 19,911 & 18300 & 1040 & 5.68 \\
\hline 2008 & 16,970 & 19300 & 1040 & 5.39 \\
\hline 2009 & 19,046 & 18900 & 1289 & 6.82 \\
\hline 2010 & 18,592 & 19500 & 1383 & 7.09 \\
\hline 2011 & 20,556 & 20500 & 1488 & 7.26 \\
\hline 2012 & 22,169 & 20100 & 1338 & 6.66 \\
\hline Total & 44,497 & $2.35 E+08$ & 16715 & 7.12 \\
\hline
\end{tabular}


Table 3 below presents the summary statistics. The left panel report summary statistics on the basis of firm/year observations where the firm has received UK subsidy in a particular year; whereas the right panel correspond to firm/year observations when the firm is not a recipient of UK subsidy in a particular year. Stated differently, the left panel provides summary statistics on the basis of firm/year observation when the firm is treated; and the right panel provides summary statistics on the basis of firm/year observation when the firm is untreated. ${ }^{3}$

Table 3: Summary statistics - 1998-2012

(Firm/year observations)

Treated (UK subsidy) Untreated (No UK subsidy)

\begin{tabular}{|c|c|c|c|c|c|c|}
\hline & Observation & Mean & Std. Dev. & Obs & Mean & Std. Dev. \\
\hline UK subsidy dummy & 195,151 & 1.00 & 0.00 & 16,429 & 0.00 & 0.00 \\
\hline EU subsidy dummy & 195,151 & 0.80 & 0.40 & 16,429 & 0.14 & 0.35 \\
\hline Privately funded R\&D (£'000) & 195,138 & 556.20 & 15424.28 & 16,405 & $6.59 \mathrm{E}+03$ & $4.63 \mathrm{E}+04$ \\
\hline Total R\&D ( $£$ '000) & 195,151 & 638.56 & 16457.67 & 16,429 & $6.59 \mathrm{E}+03$ & $4.62 \mathrm{E}+04$ \\
\hline Privately funded R\&D intensity & 193,730 & 0.80 & 36.23 & 16,039 & 1.40 & 32.99 \\
\hline Total R\&D intensity & 193,742 & 0.90 & 37.56 & 16,063 & 1.40 & 32.98 \\
\hline Deflated private R\&D & 195,138 & 622.19 & 16848.80 & 16,405 & $7.36 \mathrm{E}+03$ & $5.04 \mathrm{E}+04$ \\
\hline Deflated total R\&D & 195,138 & 715.22 & 18037.17 & 16,428 & 7357.57 & 50361.51 \\
\hline $\begin{array}{l}\text { UK central government support } \\
\left(€^{\prime} 000\right)\end{array}$ & 195,151 & 78.51 & 2945.44 & 16,429 & 0.00 & 0.00 \\
\hline EU support ( $\left(\right.$ ' $\left.^{\prime} 00\right)$ & 195,138 & 3.81 & 126.87 & 16,405 & 6.74 & 202.00 \\
\hline UK subsidy intensity & 195,151 & 0.07 & 0.09 & 13,051 & 0.00 & 0.00 \\
\hline EU subsidy intensity & 195,138 & 0.01 & 0.03 & 13,050 & 0.02 & 0.06 \\
\hline Multiple subsidy dummy & 195,151 & 0.80 & 0.40 & 16,429 & 0.00 & 0.00 \\
\hline Turnover ( $\left(\right.$ ' $\left.^{\prime} 000\right)$ & 195,150 & $2.70 \mathrm{E}+04$ & $4.15 E+05$ & 16,429 & $1.44 \mathrm{E}+05$ & $1.05 E+06$ \\
\hline Deflated turnover $\left(£^{\prime} 000\right)$ & 195,016 & $2.88 \mathrm{E}+04$ & $4.81 \mathrm{E}+05$ & 16,422 & $1.69 \mathrm{E}+05$ & $1.29 \mathrm{E}+06$ \\
\hline Deflated turnover growth & 187,038 & 0.02 & 0.67 & 15,594 & 0.03 & 0.69 \\
\hline Age & 195,151 & 16.71 & 10.39 & 16,429 & 18.81 & 10.30 \\
\hline Employment (count) & 195,150 & 146.12 & 1884.73 & 16,429 & 648.83 & 4828.83 \\
\hline UK ownership dummy & 195,151 & 0.88 & 0.33 & 16,429 & 0.78 & 0.41 \\
\hline Herfindahl index (3-digit) & 195,150 & 0.10 & 0.11 & 16,429 & 0.13 & 0.14 \\
\hline Herfindahl index squared & 195,150 & 0.02 & 0.06 & 16,429 & 0.04 & 0.09 \\
\hline Capital R\&D intensity & 193,742 & 0.04 & 2.03 & 16,063 & 0.09 & 5.18 \\
\hline Capital R\&D int. Sq. & 193,742 & 4.12 & 1006.27 & 16,063 & 26.83 & 2860.29 \\
\hline
\end{tabular}

\footnotetext{
${ }^{3}$ Minimum and maximum values are excluded to comply with non-disclosure requirements of the data host. We do not provide a similar table for cases when EU subsidy is and is NOT received to save space.
} 
R\&D personnel (scientists and technicians) (count)

$\begin{array}{llllll}195,151 & 5.66 & 83.64 & 16,429 & 36.97 & 154.80 \\ 195,151 & 0.59 & 0.49 & 16,429 & 0.24 & 0.42 \\ 195,151 & 0.34 & 0.47 & 16,429 & 0.18 & 0.38 \\ 195,151 & 0.22 & 0.42 & 16,429 & 0.11 & 0.31 \\ 195,151 & 0.10 & 0.30 & 16,429 & 0.14 & 0.34 \\ 195,151 & 0.28 & 0.45 & 16,429 & 0.43 & 0.50 \\ 195,151 & 0.06 & 0.23 & 16,429 & 0.14 & 0.35 \\ 195,151 & 92.21 & 9.48 & 16,429 & & \\ 195,151 & 0.47 & 0.50 & 16,429 & 95.80 & 7.86 \\ 195,138 & 7.93 & 0.13 & 16,428 & 0.34 & 0.47\end{array}$

The first observation to make is that the UK government support regime is highly generous: UK firms have received government support in $92 \%[(=195,151 /(195,151+16,429)]$ of the firm/year observations. The average UK subsidy intensity is $0.07(7 \%)$, with a $75^{\text {th }}$ percentile value of $9 \%$ and a $95^{\text {th }}$-percentile value of $28 \%$. The third observation is that the R\&D intensity of subsidy-receiving firm/year observations (0.8) is lower than that of non-subsidized year/firm observations (1.4). However, the mean conceals a high degree of skewness as the respective median values are 0.03 and 0.01 .

Table 3 also indicates that non-subsidized firms are usually larger and older; and have higher level of R\&D investment in R\&D-related capital such as lab equipment and buildings. Non-subsidized firm/year observations are also associated with higher levels R\&D personnel on average. Finally, more than one-third (36\%) of the R\&D-active firms in the UK are in the science-based Pavitt technology class - Pavitt 1 that includes industries such as chemicals, information technology, office machinery, precision instruments, and medical and optical instruments industries. 


\section{Method}

We use this estimation sample and a structural model with selection to estimate the effects of both UK and European Union (EU) subsidies on privately-funded R\&D investment.

The first-generation structural models (Lichtenberg, 1987) build on a demand and supply framework compatible with profit maximization, but they treat the subsidy as exogenous. Even when they relax the assumption of exogenous subsidy, all they do is to use instrumental variable (IV) techniques such as two- or three-stage least-squares (2SLS, 3SLS) (Wallsten, 2000). The 3SLS estimator allows is preferable because it allows for correlation between the error terms of the selection and outcome equations. However, the exogeneity of the instrument for subsidy is non-testable even in the 3SLS setting because the model is justidentified. Hence the 3SLS approach constitutes an improvement on the structural models, but it still does not address the issue subsidy endogeneity satisfactorily.

Endogeneity of the subsidy may be due to three reasons. First, the decision of the funding agency to grant support and the level of subsidy granted may be dependent on the firm's R\&D effort. If the funding agency selects firms on perceived R\&D effort, the OLS estimate for subsidy's effect on R\&D effort will be biased upward. Otherwise, the OLS estimate will be biased downward (Heckman, 1978; Wooldridge, 2002; Cerulli, 2010). Secondly, endogeneity may be due to ommitted variable bias that arises when the researcher does not have the necessary information about crucial variables (e.g., project quality) that affect the decision on subsidy and its level. Finally, the data may be subject to measurement error, leading to correlation between the error term and the regressors.

The structural model with selection or the endogenous binary selection model we adopt here can address the issue of subsidy endogeneity satisfactorily, provided that the error terms of the selection and outcome models satisfy the condition of joint-normality. In what follows, 
we draw on Busom (2000) and Takalo et al (2013) to specify the model and discuss the extent to which departures from joint normality may or may not be conducive to biased estimates.

Let $F^{*}$ denotes the unobserved net profit of the firm, $\mathbf{Z}$ the vector of observable variables that determine net profit, and $u$ the error term. Then the firm's net profit function can be stated as follows:

$F^{*}=f(\mathbf{Z}, u)$

Firm's decision to apply for subsidy or abstain depends on $F^{*}$. The firm decides to apply if profits net of application costs are positive. Otherwise it abstains - as stated below.

$I_{f}=\left\{\begin{array}{l}1 \text { if } F^{*} \geq 0 \\ 0 \text { if } F^{*}<0\end{array}\right.$

The funding agency's behaviour is modelled analogously, with $\mathrm{G}^{*}$ denoting the objective function of the agency, $\mathbf{W}$ is the vector of observable factors that affect the agency decision, and $v$ the error term.

$G^{*}=g(\mathbf{W}, u)$

The agency decides to grant or withhold subsidy after considering the firm's application and evaluating the effects of granting the subsidy on its own objective function $\left(G^{*}\right)$. The agency decides to grant subsidy if the decision ensures that $G^{*} \geq 0$; otherwise it withholds the subsidy.

$I_{g}= \begin{cases}1 & \text { if } G^{*} \geq 0 \\ 0 & \text { if } G^{*}<0\end{cases}$

In the data, we do not observe the firm's and the agency's decisions separately. Instead, we observe the final outcome of granting or not granting of (hence obtaining and not obtaining) the subsidy. Denoting this outcome by $I$, we can write: 


$$
I=I_{f} \cdot I_{g}=\left\{\begin{array}{l}
1 \text { if } F^{*} \geq 0 \text { and } G^{*} \geq 0 \\
0 \quad \text { Otherwise }
\end{array}\right.
$$

Using the equivalents of $\mathrm{F}^{*}$ and $\mathrm{G}^{*}$ from (2) and (4), we can re-write (5a) as follows:

$$
I=I_{f} \cdot I_{g}=\left\{\begin{array}{l}
1 \text { if } h(\mathbf{Z}, \mathbf{W}, u, v) \geq 0 \\
0 \text { if } h(\mathbf{Z}, \mathbf{W}, u, v)<0
\end{array}\right.
$$

Here $h($.$) is a function of observables in \mathbf{Z}$ and $\mathbf{W}$, and of the error terms $u$ and $v$.

Now let's specify the firm's behavioural equation with respect to investment in R\&D (i.e., the R\&D outcome equation) as follows:

$R D=\mu+\mathbf{X} \alpha+\gamma I+\varepsilon$

Here, $\mathrm{RD}$ is observed for two types of firms: (i) firms that participate in the public funding competition (when I = 1); and (ii) firms that do not participate in the funding competition (when $\mathrm{I}=0$ ). In this setting, the 'non-participants' constitute the comparator group that allows for estimating the effect of the treatment (R\&D subsidy) on the treated (firms that have applied for and received $\mathrm{R} \& \mathrm{D}$ subsidy). Combining (5b) and (6), letting $\mathbf{Q}=[\mathbf{Z}, \mathbf{W}]$, and denoting firms with subscript $i$, the system of equations for estimation becomes:

$$
\left\{\begin{array}{c}
R D_{i}=\mu_{i}+\mathbf{X}_{i} \alpha+\gamma I_{i}+\varepsilon_{i} \\
I_{i}^{*}=\theta+\mathbf{Q}_{i} \beta+e_{i} \\
I_{i}=\left\{\begin{array}{l}
1 \text { if } I_{i}^{*} \geq 0 \\
0 \text { if } I_{i}^{*}<0
\end{array}\right. \\
\operatorname{Cov}\left(\varepsilon_{i}, e_{i}\right)=\rho \neq 0
\end{array}\right.
$$


Compared with matching or OLS models that assume selection on observables, model (7) has the advantage of taking into account the effect of unobservables. This is done by assuming nonzero correlation between the error terms of the outcome and selection equations - i.e., by assuming that $\operatorname{Cov}\left(\varepsilon_{i}, e_{i}\right)=\rho \neq 0$.

This assumption, however, is not sufficient for consistent estimation if some unobservables affect both the firm's R\&D effort and its treatment status (receipt or non-receipt of subsidy) simultaneously. This is the case because we condition the selection and outcome equations only on a set of observable covariates ( $\mathbf{X}$ and $\mathbf{Q})$. Reverting to IV techniques may be appropriate - but at the expense of not being able to test for exogeneity of the instrument for subsidy. This is the case unless we have more than one instrument - a condition rarely met given that it is already difficult to find even one valid instrument in this research filed.

The good news is that the endogenous binary selection model provides a way out because it is a system of simultaneous nonlinear equations. The first is a 'selection model' for the public agency, estimated with a non-linear estimator (a probit estimator if the subsidy is observed as a binary outcome variable or a logit estimator if the subsidy is observed in levels). The second is an 'outcome model' estimated with OLS. Given this setting, the model remains formally identified thanks to its intrinsic nonlinearity.

The endogenous binary selection model in (7) can be estimated via two-step or maximum likelihood (ML) procedures. Both procedures assume joint normality for the error terms of the outcome and selection equations $\left(\varepsilon_{i}\right.$ and $\left.e_{i}\right)$. Under joint normality, both estimators are similar in terms of efficiency. However, the ML estimator is relatively less efficient if the dual normality condition is violated (Cerulli, 2010). Therefore, we use the two-step estimator. Once estimated, the model yields consistent estimates for the subsidy coefficient $(\gamma)$. 
In both models, the coefficient on subsidy $(\gamma)$ is an indicator of the effect of public support on privately-funded $R \& D$ investments. However, it is not a precise estimate if the treatment is interacted with covariates in the outcome equation. To obtain the treatment effect when treatment is interacted with covariates in the outcome model, we need to take the expected value of the difference between the outcomes of treated and non-treated firms and the covariates with which the treatment variable is interacted. Denoting the R\&D effort of the treated firms with $R D_{1 i}$ and that of the non-treated firms with $R D_{0 i}$, and recalling that the $\mathrm{R} \& \mathrm{D}$ effort is a function of the covariates in vector $\mathbf{X}$, we can write:

$$
\begin{aligned}
A T E & =E\left(R D_{1 i}-R D_{0 i}\right)=E\left\{E\left(R D_{1 i}-R D_{0 i} \mid \mathbf{x}_{\boldsymbol{i}}, \boldsymbol{\varepsilon}_{\mathbf{0} i}, \boldsymbol{\varepsilon}_{\mathbf{1 i}}\right)\right\} \\
& =E\left\{\mathbf{x}_{i}\left(\gamma_{i}-\gamma_{0}\right)\right\}
\end{aligned}
$$

The ATE in (8) is the average difference of the treatment potential outcomes and the control (non-treated) potential outcomes on the 'whole' population of both recipients and nonrecipients of the public support.

On the other hand, ATET is the average difference of the treatment potential outcomes and the control potential outcomes on the treated population. It is estimated in accordance with (9) below.

$$
\begin{aligned}
A T E T & =E\left(R D_{1 i}-R D_{0 i} \mid I_{i}=1\right)=E\left\{E\left(R D_{1 i}-R D_{0 i} \mid \mathbf{x}_{i}, \mathbf{w}, I_{i}=1\right)\right\} \\
& =E\left\{\mathbf{x}_{i}\left(\gamma_{i}-\gamma_{0}\right)+\left(\rho_{1} \sigma_{1}-\rho_{0} \sigma_{0}\right) \emptyset \frac{\left(\mathbf{w}_{i} \beta\right)}{\Phi\left(\mathbf{w}_{i} \beta\right)} \mid I_{i}=1\right\}
\end{aligned}
$$

Although the structural selection model (7) takes account of endogenous selection, it has two shortcomings. First, consistent estimation of the subsidy's effect on R\&D effort crucially depends on correct specification of the selection and outcome models. As indicated above, 
usually we do not have sufficient information about the funding regime. Even if we do, there is no commonly-agreed set of covariates that should enter the behavioural equation for the funding agency. The second problem is due to time-constant firm effects that may be due to systematic differences between firms that are not observed/measured in the data. Such firm effects may be due to differences in management quality or other path-dependent characteristics - which remain constant over time for each firm but vary across firms. If timeinvariant effects exist and if they are correlated with the regressors, pooled OLS estimates from (7) will be biased.

Wooldridge (1995) propose a conditional mean approach to correct for firm-specific effects in the selection and outcome models. The approach involves estimating inverse-Mills ratios for each year of the time dimension of the data. This involves estimating $\mathrm{T}$ probit selection models, where $\mathrm{T}$ is the number of years over which the firms are observed. The model can be specified as follows:

$$
\begin{aligned}
& R D_{i t}=\eta_{i}+\mathrm{x}_{i t}^{\prime} \alpha+\gamma I_{i t}+\varepsilon_{i t} \\
& I_{i t}=\theta_{i}+\mathrm{z}^{\prime}{ }_{i t} \beta+u_{i t}
\end{aligned}
$$

$\eta_{i}$ and $\theta_{i}$ are unobserved firm-specific effects. The firm-specific effect in the outcome equation $\left(\eta_{i}\right)$ can be eliminated by using a fixed-effect (within-group) estimator. However, the firmspecific effect in the selection model $\left(\theta_{i}\right)$ cannot be eliminated with the same method because the selection model is non-linear and estimated with a probit estimator. Wooldridge (1995) draws on Chamberlain's conditional mean theorem and demonstrates that the unobserved $\theta_{i}$ can be substituted by inverse-Mills ratio for each firm/year observation by running $\mathrm{T}$ crosssection probit estimations. Then the outcome model to be estimated boils down to: 
$R D_{i t}=\eta_{i}+\mathrm{x}_{i t}^{\prime} \alpha+\gamma I_{i t}+\delta\left(I_{n} v_{-} M i l l s\right)_{i t}+v_{i t}$

Model (11) can be estimated consistently using a fixed-effect estimator. The coefficient on the intervention variable $(\gamma)$ will be unbiased because its estimation takes account of the selection rule through inclusion of the inverse-Mills ratio and is carried out after eliminating the firmspecific effects $\left(\eta_{i}\right)$. However, and just as it was the case with respect to the endogenous binary selection model, the consistency of the estimate for the subsidy effect depends on correct specification of the selection and outcome equations. Given that correct model specification is essential for consistent estimates, we use the same set of covariates for the selection and outcome equations in bot endogenous binary selection and conditional mean estimations. Then, the difference between the two can be interpreted as the bias that arises from failure to eliminate the firm-specific time-constant effects in the estimation of the endogenous binary selection model.

Given these methodological considerations, we will provide estimates based on different estimators. This is to verify if the 'treatment effect' (i.e., the effect of subsidy receipt on privately-funded R\&D) differs between estimators, depending on whether they control for endogeneity of the subsidy and eliminate the time-constant firm effects. The results will include OLS and fixed-effect estimates not corrected for selection bias, followed by structural selection model estimations from (7) and selection-corrected fixed-effect estimates from (11). Given that we have a panel dataset, our preferred estimator is Wooldridge's fixed-effect estimator, which corrects for endogeneity of the subsidy and is carried out after eliminating the time-constant firm effects. 
The estimations results will provide an indication of whether UK government or EU support has a complementary or substitution effect on firm's private R\&D intensity. Having established whether we observe a complementary or substitution effect, we will also check whether the effect of subsidy on R\&D effort varies between firms with different levels of subsidy intensity. In other words, we will try to identify the class(es) of firms where subsidy intensity is more (or less) likely to leverage private $R \& D$ investment. This is an important issue given that the $R \& D$ intensity of UK firms has been and is still low in comparison to international standards (Hughes and Milna, 2012).

To address this question, we use an ordered-probit selection model proposed by Chiburis and Lokshin (2007). This model allows for sorting the firms into J+1 classes of 0, 1, $2, \ldots \mathrm{J}$ on the basis of an ordered-probit selection rule where the latent selection variable $\left(z_{i}^{*}\right)$ is not observable but the categorical variable $\left(z_{i}\right)$ is observable and depends on particular realisations of the latent variable. Then, we can specify the selection rule as follows (Chiburis and Lokshin, 2007):

$$
\begin{aligned}
& z^{*}=\beta^{\prime} w_{i}+u_{i} ; \quad \text { and } \\
& z_{i}=\left\{\begin{array}{llr}
0 & \text { if }-\infty<z_{i}<\mu_{1} \\
1 & \text { if } & \mu_{1}<z_{i}<\mu_{2} \\
2 & \text { if } & \mu_{2}<z_{i}<\mu_{3} \\
\cdot & \\
\text { j } & \text { if } & \mu_{J}<z_{i}<\infty
\end{array}\right.
\end{aligned}
$$

The latent selection variable refers to subsidy intensity. In other words, we assume that firms belong to different classes of subsidy intensity as a result of a two-way selection process that we do not observe: selection by the firm to apply for subsidy and selection by the funding agency to award a given applicant. Given this setting, the outcome (R\&D effort) is a linear 
function of a set of covariates in $\mathbf{x}_{\mathbf{i}}$ and the coefficients $\left(\alpha_{0}, \ldots \alpha_{j}\right)$ vary between categorical classes of $z_{i}$. Then, the R\&D effort equation can be written as follows:

$$
R D_{i}= \begin{cases}\alpha^{\prime}{ }_{0} \mathrm{x}_{i}+\varepsilon_{i 0} & \text { if } z_{i}=0 \\ \alpha^{\prime}{ }_{1} \mathrm{x}_{i}+\varepsilon_{i 1} & \text { if } z_{i}=1 \\ \alpha^{\prime}{ }_{2} \mathrm{x}_{i}+\varepsilon_{i 2} & \text { if } z_{i}=2 \\ \cdot & \\ \dot{\alpha}_{J}^{\prime} \mathrm{x}_{i}+\varepsilon_{i J} & \text { if } z_{i}=J\end{cases}
$$

Here the categorical variable $z_{i}=0$ is the class of firms that do not receive subsidy in a particular year; and the remaining classes $1, \ldots J$ are sorted on the basis of increasing subsidy intensity. The latter is defined as the ratio of UK or EU public support to total R\&D expenditures. The model in (12a) and (12b) can be estimated through a two-step procedure or via maximum likelihood (ML). The necessary condition for consistent estimation of the model is the same as the selection model in (7) above: the error terms of the selection and outcome equations $\left(u_{i}\right.$ and $\left.\varepsilon_{i}\right)$ must satisfy the condition of joint normality. The two-step procedure is more efficient than ML if normality condition is violated. Therefore, we estimate the model with a two-step consistent estimator.

We define the subsidy intensity classes as follows: $z i=0$ is the group consisting of firm/year observations when subsidy intensity is zero; $z i=1$ is the group consisting of firm/year observations where subsidy intensity is greater than zero but less than or equal to the value at the $25^{\text {th }}$ percentile; $z i=2$ is the group consisting of firm/year observations where subsidy intensity is between the $25^{\text {th }}$ percentile and median; $z i=3$ is the group consisting of firm/year observations where subsidy intensity is between the median and the $75^{\text {th }}$ percentile; and $z i=4$ is the group consisting of firm/year observations where subsidy intensity is greater than the value at the $75^{\text {th }}$ percentile. 


\section{Findings}

Given the methodological framework above, the selection and outcome models we estimate are as follows:

$$
\begin{aligned}
& S u b_{-} d u m_{i t}=\beta_{0}+\beta_{1} \text { size_dum }_{i t}+\beta_{2} \text { startup_dum }_{i t}+\beta_{3} \text { lcap_RD_int }_{i t-1} \\
& +\beta_{4} l^{2} c a p \_R D \_i n t_{i t-1}+\beta_{5} l R D \_p e r s_{i t-1}+\beta_{6} l^{2} R D \_p e r s_{i t-1} \\
& +\beta_{7} \text { lempl }_{i t-1}+\beta_{8} l^{2} \text { empl }_{i t-1}+\beta_{9} \text { growt }_{i t}+\beta_{10} \text { def_RD } D_{i t} \\
& +\beta_{11} \text { Pavitt }_{i t}+\beta_{12} \text { Pavitt }_{i t}+\beta_{13} \text { Pavitt }_{i t}+\beta_{14} \text { Pavitt }_{i t}+u_{i t}
\end{aligned}
$$

(Selection equation)

$\log _{-} P r i v_{-} R D_{-} i n t_{i t}$

$$
\begin{aligned}
& =\alpha_{0}+\gamma S u b_{-} \text {dum }_{i t} \alpha_{1} \text { loutput }_{i t}+\alpha_{2} l^{2} \text { output }_{i t}+\alpha_{3} \text { lage }_{i t} \\
& +\alpha_{4} l^{2} a g e_{i t}+\alpha_{5} l e m p l_{i t}+\alpha_{6} l^{2} e m p l_{i t}+\alpha_{7} u k_{-} \text {owned } d_{i t}+\alpha_{8} H I_{i t} \\
& +\alpha_{9} \text { HI_sq }_{i t}+\alpha_{10} \text { Pavitt }_{i t}+\alpha_{11} \text { Pavitt }_{i t}+\alpha_{12} \text { Pavitt }_{i t} \\
& +\alpha_{13} \text { Pavitt }_{i t}+\alpha_{14} \text { AEER }_{i t}+\alpha_{15} \text { crisis }_{i t}+\alpha_{16} \text { lFTSE }_{i t}+\alpha_{17} \text { multi_sub } b_{i t} \\
& +\alpha_{18} \text { inverse_Mills }+\varepsilon_{i t}
\end{aligned}
$$

(Outcome equation)

Sub_dum is the dependent variable in the selection model and it is 1 if the firm receives public support in a particular year. On the other hand, Log_Priv_RD_int is the dependent variable in the outcome model and it measures the intensity of privately-funded $R \& D$ expenditures as a ratios of turnover. The privately-funded $R \& D$ intensity is augmented with 1 before its logarithm is taken. 
In the selection model, we assume that the funding agency selects applicants on the basis of certain firm characteristics, including a size dummy that depicts SMEs with less than 250 employees (size_dum); whether the firm is was born in 1998 or thereafter (startup_dum); intensity of $\mathrm{R} \& \mathrm{D}$ investment in research labs and equipment (cap_RD_int) and its square; number of R\&D personnel (i.e., scientists and technicians) employed (RD_pers ) and its square; firm age (age) and its square; number of employees (empl) and its square; growth rate of deflated turnover between year t-1 and $\mathrm{t}$ (growth); whether the firm is engaged in defencerelated R\&D (def_RD); and the firm's membership of Pavitt technology classes. A prefix $(l)$ indicates that the variable is in logs, a prefix $\left(l^{2}\right)$ indicates squared value of the logged variable, and a subscript (t-1) indicates that the variable is lagged one year. The lagged value is used as we assume that the funding agency evaluates the firm on the basis of the latter's annual statement (which provides information about the previous year). The squared values (the quadratic terms) are included to establish whether the funding agency's selection decisions change at different levels of the firm characteristic in question.

Covariates in the selection model are chosen on the basis of the information discussed in section 3 above. The discussion there draws on technology strategy documents published by the Department for Business, Innovation and Skills (BIS), various funding schemes/competitions publicised on the Innovate $U K$ website, interviews with Innovate UK staff; and from modelling work in the relevant literature.

A similar approach has been adopted in specifying the outcome model. The level of deflated output (turnover) and its square is included because they can be considered as proxies for the cash flow available to the firm. In the R\&D investment literature, cash flow is usually reported to be a significant determinant of $R \& D$ investment (Brown et al., 2009; Hall et al., 1998). Age is also a frequently-cited determinant of R\&D investment, with older firms reported to have lower innovation intensities (Huergo and Jaumandreu, 2004; Balasubramanian and Lee, 
2008). There is also a long-standing debate about whether firm size and innovation intensity are related (see, Cohen et al., 1987; Shefer and Frenkel, 2005; and Tsai and Wang, 2005). Concentration at 3-digit industry level is included in line with Schumpeterian models of competition and innovation (Aghion et al, 2005; Polder and Veldhuizen, 2012).

Finally, we include dummies for Pavitt technology classes, treating the unclassified industries (Pavitt5) as the excluded category. Pavitt class 1 consists of firms in science-based industries (e.g., chemicals, office machinery, precision, medical and optical instruments industries, ICT, etc.). Pavitt class 2 consists of industries that are specialized suppliers of technology or capital goods to other industries (e.g., mechanical engineering industries, manufacturers of electrical machinery, equipment hire\&lease industries, and business services suppliers, etc.). Pavitt class 3 consists of scale-intensive industries such as pulp\&paper, transport vehicles, mineral oil refining industries, financial intermediaries, etc.). Pavitt class 4 consists of technology-supplier-dominated industries such as textiles \& clothing, food \& drink, fabricated metals, etc.

Table 4 below presents probit estimation results for the selection model. The exclusion restriction is ensured by using a size dummy that features in the selection of both UK government and the European union funding rule. This dummy is equal 1 if the firm is classified as small-to-medium-sized (SME) in both regimes; and zero otherwise. This dummy is not included in the outcome models. When checked in conjunction with other covariates in the outcome model, the size dummy is not correlated with the private R\&D intensity, which is the dependent variable. Hence, we are satisfied that the size dummy complies with the necessary condition for exclusion restriction. 
Table 4: Probit estimation of the selection model

(Dependent variable: Subsidy dummy)

\begin{tabular}{|c|c|c|c|}
\hline Regressor & Description/measurement & UK Regime & EU regime \\
\hline Size dummy & $=1$ if firm employment $<250$ & $\begin{array}{c}0.116^{* * *} \\
(0.0233)\end{array}$ & $\begin{array}{l}0.0698^{* * *} \\
(0.0189)\end{array}$ \\
\hline Start-up firm & $=1$ if new entrant & $\begin{array}{c}0.147^{* * *} \\
(0.0144)\end{array}$ & $\begin{array}{l}-0.0866^{* * *} \\
(0.00923)\end{array}$ \\
\hline Lagged Capital R\&D int. & Log (int. +1), lagged 1 year & $\begin{array}{l}-0.379^{* * *} \\
(0.0815)\end{array}$ & $\begin{array}{l}-0.224^{* * *} \\
(0.0657)\end{array}$ \\
\hline Lagged Capital R\&D int. sq. & Log squared, lagged 1 year & $\begin{array}{c}0.0547^{* *} \\
(0.0234)\end{array}$ & $\begin{array}{c}0.0180 \\
(0.0201)\end{array}$ \\
\hline $\mathrm{R} \& \mathrm{D}$ personnel & Log, lagged 1 year & $\begin{array}{c}-0.126^{* * *} \\
(0.00445)\end{array}$ & $\begin{array}{c}-0.106^{* * *} \\
(0.00337)\end{array}$ \\
\hline $\mathrm{R} \& \mathrm{D}$ personel sq. & Log squared, lagged 1 year & $\begin{array}{c}-0.0452^{* * *} \\
(0.000716)\end{array}$ & $\begin{array}{c}-0.0350^{* * *} \\
(0.000589)\end{array}$ \\
\hline Growth & Growth of deflated t/over & $\begin{array}{c}0.0176^{* *} \\
(0.00884)\end{array}$ & $\begin{array}{c}0.0144^{* *} \\
(0.00605)\end{array}$ \\
\hline Employment & Log, lagged 1 year & $\begin{array}{l}-0.101^{* * *} \\
(0.0128)\end{array}$ & $\begin{array}{l}-0.0229^{* *} \\
(0.00927)\end{array}$ \\
\hline Employment sq. & Log squared, lagged 1 year & $\begin{array}{c}0.0176^{* * *} \\
(0.00151)\end{array}$ & $\begin{array}{c}0.0133^{* * *} \\
(0.00120)\end{array}$ \\
\hline Defense R\&D active & $=1$ if firm engages in defense $R \& D$ & $\begin{array}{c}0.688^{* * *} \\
(0.0125)\end{array}$ & $\begin{array}{c}0.251^{* * *} \\
(0.00802)\end{array}$ \\
\hline Pavitt class 1 & Science-based & $\begin{array}{c}0.671^{* * *} \\
(0.0246)\end{array}$ & $\begin{array}{c}1.784^{* * *} \\
(0.0177)\end{array}$ \\
\hline Pavitt class 2 & Specialized supplier of tech. & $\begin{array}{c}0.598^{* * *} \\
(0.0252)\end{array}$ & $\begin{array}{c}1.278^{* * *} \\
(0.0167)\end{array}$ \\
\hline Pavitt class 3 & Scale-intensive & $\begin{array}{c}0.233^{* * *} \\
(0.0244)\end{array}$ & $\begin{array}{c}0.841^{* * *} \\
(0.0177)\end{array}$ \\
\hline Pavitt class 4 & Supplier-dominated & $\begin{array}{c}0.0245 \\
(0.0211)\end{array}$ & $\begin{array}{c}0.168^{* * *} \\
(0.0153)\end{array}$ \\
\hline Constant & Constant & $\begin{array}{c}1.121^{* * *} \\
(0.0416)\end{array}$ & $\begin{array}{l}-0.318^{* * *} \\
(0.0299)\end{array}$ \\
\hline sigma & & 0.269 & 0.293 \\
\hline Rho & & 0.827 & 0.796 \\
\hline Lambda (sigma*Rho) & & $\begin{array}{c}0.223^{* * *} \\
(0.00405)\end{array}$ & $\begin{array}{c}0.233^{* * *} \\
(0.00505)\end{array}$ \\
\hline Observations & & 162733 & 162733 \\
\hline
\end{tabular}

Excluded category for Pavitt classes is class 5, which consists of un-classified industries

Comparing the UK and EU regimes, we can see that in both regimes the probability of granting subsidies is higher if the firm is SME or it records stronger growth performance in the previous 
year. The two regimes are also similar in their approach to size (employment headcount): the two agencies tend to favour smaller firms when the number employed is small to begin with, but this preference is reversed after a threshold of employment is exceeded.

The third and fourth similarities provide some indication about whether the regimes are 'picking up winners' or 'aiding the poor'. The probit results indicate that firms with higher levels of investment in R\&D-related capital (labs, equipment, instruments, etc.) are less likely to receive UK or EU subsidies - albeit the probability of receiving UK subsidy begins to increase after a certain threshold is reached. In addition, the evidence also indicates that the probability of receiving subsidy decreases in both regimes as the number of $\mathrm{R} \& \mathrm{D}$ personnel employed increases. Indeed, the probability of receiving subsides falls at higher rates as the number of R\&D personnel is beyond a certain threshold. These findings indicate that both the UK and EU regimes tend to 'aid the poor' rather than 'pick up winners'. Stated differently, firms that can be expected to have higher levels of $R \& D$ expenditures due to their existing investment in R\&D-related capital and/or employment of R\&D personnel (scientists and technicians) are not favoured by either UK or EU funding regimes.

Despite these similarities, the two regimes differ with respect to two firm- or industryspecific factors. First, there is evident contrast between the UK regime where a start-up company is more likely to receive subsidy and the EU regime where such company is less likely to receive subsidy. Secondly, there is strong evidence that a firm is more likely to receive EU subsidy (compared to UK subsidy) if it is in Pavitt technology classes 1, 2 and 3. These are: firms in science-based technology class (class 1); firms specialised in the supply of technology to other industries (class 2); and scale-intensive firms (e.g. automotive, pulp\&paper, mining, etc.) (class3). These differences indicate that firms are more likely to apply and receive EU subsidies if they are well-established and operate within certain technology classes where the capacity to plan and undertake long-term $R \& D$ projects is higher. 
Table 5 presents the estimation results for the outcome equation, using four different estimators: (1) pooled OLS with no selection correction; (2) fixed-effects with no selection correction; (3) pooled OLS with correction for selection on observable and unobservables; and (4) fixed-effects with selection correction for observables and unobservables. The coefficient on the UK subsidy dummy is negative and significant in 3 out 4 estimations, indicating that firms substitute the subsidy for privately-funded R\&D. However, we know that the first two results are biased since they do not take account of selection. The third does take account of selection and indicates a high level of crowding out. This is the result obtained by estimating the endogenous binary selection model in (7) above. The model corrects for selection bias, but the consistency of its estimates depends on correct specification of the selection and outcome models. In addition, the OLS estimation of the outcome model does not take account of firmspecific effects that may be correlated with the covariates. Therefore, we prefer model (4), which controls for both selection and firm-specific fixed effects (Greene, 1995). The result form model 4 indicates that UK subsidy has no additionality effect on the intensity of privatelyfunded R\&D. 
Table 5: Effect of UK subsidy on Private R\&D intensity - full sample (Dependent variable: Log of Private R\&D intensity)

\begin{tabular}{|c|c|c|c|c|}
\hline & (1) & $(2)$ & (3) & $(4)$ \\
\hline \multirow[t]{2}{*}{ UK subsidy dummy } & $-0.0442^{* * *}$ & $-0.0133^{* * *}$ & $-0.462^{* * *}$ & 0.00284 \\
\hline & $(0.00629)$ & $(0.00413)$ & $(0.00808)$ & $(0.00466)$ \\
\hline \multirow[t]{2}{*}{ Log (Deflated turnover) } & $-0.437^{* * *}$ & $-0.517^{* * *}$ & $-0.433^{* * *}$ & $-0.523^{* * *}$ \\
\hline & $(0.00643)$ & $(0.00847)$ & $(0.00139)$ & $(0.00972)$ \\
\hline \multirow[t]{2}{*}{ Log(Def. turnover sq.) } & $0.0215^{* * *}$ & $0.0254^{* * *}$ & $0.0210^{* * *}$ & $0.0256^{* * *}$ \\
\hline & $(0.000388)$ & $(0.000603)$ & $(0.000104)$ & $(0.000691)$ \\
\hline \multirow[t]{2}{*}{ Log(Age) } & $0.0115^{*}$ & $0.137^{* * *}$ & -0.00142 & $0.178^{* * *}$ \\
\hline & $(0.00698)$ & $(0.0123)$ & $(0.00667)$ & $(0.0225)$ \\
\hline \multirow[t]{2}{*}{$\log ^{2}$ (Age) } & $-0.00848^{* * *}$ & $-0.0234^{* * *}$ & $-0.00688^{* * *}$ & $-0.0247^{* * *}$ \\
\hline & $(0.00138)$ & $(0.00282)$ & $(0.00130)$ & $(0.00469)$ \\
\hline \multirow[t]{2}{*}{ Log(Employment) } & $0.381^{* * *}$ & $0.242^{* * *}$ & $0.405^{* * *}$ & $0.251^{* * *}$ \\
\hline & $(0.00770)$ & $(0.00800)$ & $(0.00182)$ & $(0.00878)$ \\
\hline \multirow[t]{2}{*}{$\log ^{2}$ (Employment) } & $-0.0357^{* * *}$ & $-0.0240^{* * *}$ & $-0.0393^{* * *}$ & $-0.0246^{* * *}$ \\
\hline & $(0.000789)$ & $(0.000948)$ & $(0.000237)$ & $(0.00103)$ \\
\hline \multirow[t]{2}{*}{ UK ownership dummy } & $-0.0119^{* * *}$ & $0.00620^{*}$ & $-0.00541^{* * *}$ & $0.00676^{*}$ \\
\hline & $(0.00383)$ & $(0.00328)$ & $(0.00194)$ & $(0.00355)$ \\
\hline \multirow[t]{2}{*}{ Herfindahl index } & $0.0696^{* * *}$ & -0.0269 & $0.0820^{* * *}$ & 0.0267 \\
\hline & $(0.0217)$ & $(0.0174)$ & $(0.0157)$ & $(0.0190)$ \\
\hline \multirow[t]{2}{*}{ Herfindahl index sq. } & $-0.0733^{* *}$ & 0.0111 & $-0.0810^{* * *}$ & $-0.0484^{*}$ \\
\hline & $(0.0363)$ & $(0.0240)$ & $(0.0244)$ & $(0.0259)$ \\
\hline \multirow[t]{2}{*}{ Pavitt class 1} & $0.113^{* * *}$ & 0.0285 & $0.147^{* * *}$ & $0.0483^{* *}$ \\
\hline & $(0.00990)$ & $(0.0200)$ & $(0.00918)$ & $(0.0233)$ \\
\hline \multirow[t]{2}{*}{ Pavitt class2 } & $0.0340^{* * *}$ & -0.00803 & $0.0739^{* * *}$ & 0.00938 \\
\hline & $(0.00777)$ & $(0.0166)$ & $(0.00789)$ & $(0.0187)$ \\
\hline \multirow[t]{2}{*}{ Pavitt class 3} & $0.0538^{* * *}$ & 0.00637 & $0.0749^{* * *}$ & 0.0136 \\
\hline & $(0.00782)$ & $(0.0170)$ & $(0.00769)$ & $(0.0189)$ \\
\hline \multirow[t]{2}{*}{ Pavitt class 4} & 0.00853 & -0.00180 & $0.0303^{* * *}$ & 0.000856 \\
\hline & $(0.00690)$ & $(0.0156)$ & $(0.00726)$ & $(0.0172)$ \\
\hline \multirow[t]{2}{*}{ Aver. Real Eff. Exch. Rate } & $-0.00316^{* * *}$ & $-0.00240^{* * *}$ & $-0.00306^{* * *}$ & $-0.00261^{* * *}$ \\
\hline & $(0.000176)$ & $(0.000168)$ & $(0.000205)$ & $(0.000194)$ \\
\hline \multirow[t]{2}{*}{ Crisis dummy } & $-0.0222^{* * *}$ & $-0.0258^{* * *}$ & $-0.0138^{* * *}$ & $-0.0372^{* * *}$ \\
\hline & $(0.00328)$ & $(0.00318)$ & $(0.00387)$ & $(0.00406)$ \\
\hline \multirow[t]{2}{*}{ Log(FTSE-100) } & $-0.0506^{* * *}$ & $-0.0628^{* * *}$ & $-0.0385^{* * *}$ & $-0.0797^{* * *}$ \\
\hline & $(0.00465)$ & $(0.00484)$ & $(0.00499)$ & $(0.00551)$ \\
\hline \multirow[t]{2}{*}{ Multiple subsidy dummy } & -0.00254 & $0.00807^{* * *}$ & $-0.00382^{* *}$ & $0.00380^{* *}$ \\
\hline & $(0.00263)$ & $(0.00168)$ & $(0.00194)$ & $(0.00174)$ \\
\hline \multirow{2}{*}{\multicolumn{4}{|c|}{ Inverse Mills - UK }} & $0.0809^{* * *}$ \\
\hline & & & & $(0.00608)$ \\
\hline \multirow[t]{2}{*}{ Constant } & $2.072^{* * *}$ & $2.424^{* * *}$ & $2.293^{* * *}$ & $2.444^{* * *}$ \\
\hline & $(0.0480)$ & $(0.0612)$ & $(0.0451)$ & $(0.0784)$ \\
\hline \multicolumn{3}{|l|}{ lambda } & $0.223^{* *}$ & \\
\hline \multicolumn{3}{|l|}{ sigma } & 0.269 & 0.328 \\
\hline \multicolumn{3}{|l|}{ rho } & 0.827 & 0.675 \\
\hline Observation & 209652 & 209652 & 162733 & 162733 \\
\hline
\end{tabular}

Cluster-robust standard errors are in parentheses. All estimations include 2-digit industry dummies. Time dummies are not included as the crisis dummy, the FTSE-100 and the average effective exchange rates capture time variation. (1) and (2) are pooled OLS and Fixed-effect without selection correction; (3) is pooled OLS with selection correction; and (4) is FE with selection correction. ${ }^{*} p<0.10,{ }^{* *} p<0.05,{ }^{* * *} p<0.01$ 
Table 6 below replicates the same set of estimations for EU subsidy. For the same reasons indicated above, we prefer the estimate from model (4). In contrast to UK subsidies, EU subsidies have an additionality effect as the coefficient on EU subsidy is positive and significant. This result suggests that the UK selection regime can learn from EU experience in order to leverage more private $\mathrm{R} \& \mathrm{D}$ effort from supported firms.

Table 6: Effect of EU R\&D subsidy on Private R\&D intensity - full sample (Dependent variable: Log of Private R\&D intensity)

\begin{tabular}{|c|c|c|c|c|}
\hline & (1) & $(2)$ & (3) & (4) \\
\hline \multirow[t]{2}{*}{ EU subsidy dummy } & $0.0314^{* *}$ & $0.0128^{* *}$ & $-0.370^{* * *}$ & $0.0207^{* * *}$ \\
\hline & $(0.0136)$ & $(0.00546)$ & $(0.0117)$ & $(0.00789)$ \\
\hline \multirow[t]{2}{*}{ Log (Deflated turnover) } & $-0.437^{* * *}$ & $-0.517^{* * *}$ & $-0.434^{* * *}$ & $-0.523^{* * *}$ \\
\hline & $(0.00643)$ & $(0.00847)$ & $(0.00143)$ & $(0.00973)$ \\
\hline \multirow[t]{2}{*}{ Log(Def. turnover sq.) } & $0.0215^{* * *}$ & $0.0254^{* * *}$ & $0.0212^{* * *}$ & $0.0256^{* * *}$ \\
\hline & $(0.000387)$ & $(0.000603)$ & $(0.000106)$ & $(0.000693)$ \\
\hline \multirow{2}{*}{$\log ($ Age $)$} & $0.0119^{*}$ & $0.138^{* * *}$ & 0.00433 & $0.204^{* * *}$ \\
\hline & $(0.00700)$ & $(0.0123)$ & $(0.00673)$ & $(0.0225)$ \\
\hline \multirow[t]{2}{*}{$\log ^{2}$ (Age) } & $-0.00865^{* * *}$ & $-0.0240^{* * *}$ & $-0.00668^{* * *}$ & $-0.0344^{* * *}$ \\
\hline & $(0.00139)$ & $(0.00279)$ & $(0.00131)$ & $(0.00460)$ \\
\hline \multirow[t]{2}{*}{ Log(Employment) } & $0.381^{* * *}$ & $0.242^{* * *}$ & $0.404^{* * *}$ & $0.249^{* * *}$ \\
\hline & $(0.00767)$ & $(0.00799)$ & $(0.00193)$ & $(0.00877)$ \\
\hline \multirow[t]{2}{*}{$\log ^{2}$ (Employment) } & $-0.0356^{* * *}$ & $-0.0239^{* * *}$ & $-0.0385^{* * *}$ & $-0.0240^{* * *}$ \\
\hline & $(0.000781)$ & $(0.000948)$ & $(0.000249)$ & $(0.00103)$ \\
\hline \multirow[t]{2}{*}{ UK ownership dummy } & $-0.0124^{* * *}$ & $0.00626^{*}$ & $-0.00599^{* * *}$ & $0.00684^{*}$ \\
\hline & $(0.00388)$ & $(0.00328)$ & $(0.00196)$ & $(0.00357)$ \\
\hline \multirow[t]{2}{*}{ Herfindahl index } & $0.0674^{* * *}$ & -0.0273 & $0.0919^{* * *}$ & 0.0289 \\
\hline & $(0.0216)$ & $(0.0175)$ & $(0.0157)$ & $(0.0191)$ \\
\hline \multirow[t]{2}{*}{ Herfindahl index sq. } & $-0.0705^{*}$ & 0.0119 & $-0.0916^{* * *}$ & $-0.0489^{*}$ \\
\hline & $(0.0360)$ & $(0.0240)$ & $(0.0243)$ & $(0.0260)$ \\
\hline \multirow[t]{2}{*}{ Pavitt class 1} & $0.111^{* * *}$ & 0.0282 & $0.313^{* * *}$ & $0.0478^{* *}$ \\
\hline & $(0.00990)$ & $(0.0200)$ & $(0.0101)$ & $(0.0233)$ \\
\hline \multirow[t]{2}{*}{ Pavitt class 2} & $0.0320^{* * *}$ & -0.00802 & $0.208^{* * *}$ & 0.00917 \\
\hline & $(0.00773)$ & $(0.0166)$ & $(0.00858)$ & $(0.0184)$ \\
\hline \multirow{2}{*}{ Pavitt class 3} & $0.0516^{* * *}$ & 0.00632 & $0.182^{* * *}$ & 0.0167 \\
\hline & $(0.00780)$ & $(0.0170)$ & $(0.00811)$ & $(0.0187)$ \\
\hline \multirow[t]{2}{*}{ Pavitt class 4} & 0.00644 & -0.00165 & $0.0560^{* * *}$ & 0.00390 \\
\hline & $(0.00687)$ & $(0.0156)$ & $(0.00726)$ & $(0.0169)$ \\
\hline \multirow[t]{2}{*}{ Aver. Real Eff. Exch. Rate } & $-0.00290^{* * *}$ & $-0.00232^{* * *}$ & $-0.00244^{* * *}$ & $-0.00183^{* * *}$ \\
\hline & $(0.000169)$ & $(0.000165)$ & $(0.000203)$ & $(0.000174)$ \\
\hline \multirow[t]{2}{*}{ Crisis dummy } & $-0.0197^{* * *}$ & $-0.0238^{* * *}$ & $-0.00701^{*}$ & $-0.0171^{* * *}$ \\
\hline & $(0.00323)$ & $(0.00300)$ & $(0.00388)$ & $(0.00341)$ \\
\hline \multirow[t]{2}{*}{ Log(FTSE-100) } & $-0.0451^{* * *}$ & $-0.0609^{* * *}$ & $-0.0400^{* * *}$ & $-0.0609^{* * *}$ \\
\hline & $(0.00457)$ & $(0.00474)$ & $(0.00501)$ & $(0.00531)$ \\
\hline \multirow[t]{2}{*}{ Multiple subsidy dummy } & $-0.0470^{* * *}$ & -0.00728 & $-0.0450^{* * *}$ & $-0.0149^{*}$ \\
\hline & $(0.0137)$ & $(0.00536)$ & $(0.00762)$ & $(0.00767)$ \\
\hline \multirow[t]{2}{*}{ Inverse Mills - EU } & & & & $0.0138^{* * *}$ \\
\hline & & & & $(0.00253)$ \\
\hline \multirow[t]{2}{*}{ Constant } & $1.971^{* * *}$ & $2.391^{* * *}$ & $1.989^{* * *}$ & $2.223^{* * *}$ \\
\hline & $(0.0444)$ & $(0.0594)$ & $(0.0443)$ & $(0.0747)$ \\
\hline lambda & & & 0.233 & \\
\hline sigma & & 0.332 & 0.293 & 0.330 \\
\hline rho & & 0.657 & 0.796 & 0.677 \\
\hline $\mathrm{N}$ & 209652 & 209652 & 162733 & 162733 \\
\hline
\end{tabular}


NOTE: Cluster-robust standard errors are in parentheses. All estimations include 2-digit industry dummies. Time dummies are not included as the crisis dummy, the FTSE-100 and the average effective exchange rates capture time variation. (1) and (2) are pooled OLS and Fixed-effect without selection correction; (3) is pooled OLS with selection correction; and (4) is FE with selection correction. ${ }^{*} p<0.10,{ }^{* *} p<0.05,{ }^{* * *} p<0.01$

Tables A1 and A2 in the Appendix replicate the estimations in Tables 5 and 6, using data for firms in the manufacturing sector only. Results from the preferred estimator (i.e., the fixed-effect estimator corrected for selection) also indicate an additionality effect in the case of EU subsidy (an effect of 1.92\%). The results for manufacturing also indicate additionality in the case of UK subsidy too, but the effect $(0.9 \%)$ is too small to be economically significant.

These findings indicate that when a firm switches from a non-subsidised to a subsidised status, its privately-funded R\&D intensity increases by $2 \%$ in the case of EU subsidy in the manufacturing sample or the full sample. However UK subsidy has no effect in the full sample, and the additionality effect is less than $1 \%(0.9 \%)$ in the manufacturing sector. Overall, these findings indicate that the EU regime is more successful in leveraging additionality compared to the UK regime.

We have also estimated an ordered-Heckman model (12a and 12b) with a view to identify the variation in the relationship between subsidy intensity and private R\&D intensity. The results are presented in Tables 7 and 8 (for UK and EU subsidy intensity classes, respectively). The covariate of interest (UK or EU subsidy intensity) consists of four subsidy intensity classes, where each class corresponds to a quartile of the subsidy intensity distribution. The number in the column headings $(1,2,3,4)$ indicates estimations results for subsidy intensity classes that correspond to the $1^{\text {st }}, 2^{\text {nd }}, 3^{\text {rd }}$ and $4^{\text {th }}$ quartiles of the subsidy intensity distribution. The coefficient on the subsidy intensity indicate the extent to which UK (or EU) funders can leverage private R\&D additionality by increasing the subsidy within a particular subsidy intensity class. 
Results in Table 7 below indicate that UK funders would be unable to leverage additional private R\&D effort in any of the subsidy intensity classes. In fact, a $1 \%$ increase in UK subsidy intensity is associated with additional crowding-out effects of $-1.732 \%$ in subsidy intensity class 2 and a crowding-out effect of $-0.131 \%$ in intensity class 4 . In contrast, an increase of $1 \%$ in EU subsidy intensity can leverage an additional private R\&D intensity by $4.833 \%$ in subsidy intensity class 3 . Nevertheless, an increase of $1 \%$ in EU subsidy intensity is associated with a high degree of crowding out $(-18.46 \%)$ in subsidy intensity class 2 . The results from both UK and EU subsidy intensity classes are consistent in the sense that subsidy intensity class 2 is the least likely class for leveraging additional R\&D effort by increasing the generosity of the subsidy granted.

Table 7: Ordered Heckman estimates for UK subsidy intensity classes: [Dependant variable: Log (Private R\&D intensity + 1)

\begin{tabular}{|c|c|c|c|c|}
\hline & Class 1 & Class 2 & Class 3 & Class 4 \\
\hline Log(UK subsidy intensity + 1) & $\begin{array}{c}-0.328 \\
(0.553)\end{array}$ & $\begin{array}{c}-1.702^{* * *} \\
(0.304)\end{array}$ & $\begin{array}{l}-0.0335 \\
(0.0666)\end{array}$ & $\begin{array}{l}-0.131^{* * *} \\
(0.0161)\end{array}$ \\
\hline Log (Deflated turnover) & $\begin{array}{c}-0.401^{* * *} \\
(0.00272)\end{array}$ & $\begin{array}{c}-0.485^{* * *} \\
(0.00266)\end{array}$ & $\begin{array}{l}-0.401^{* * *} \\
(0.00247)\end{array}$ & $\begin{array}{c}-0.523^{* * *} \\
(0.00281)\end{array}$ \\
\hline Log(Def. turnover sq.) & $\begin{array}{c}0.0194^{* * *} \\
(0.000194)\end{array}$ & $\begin{array}{c}0.0253^{* * *} \\
(0.000210)\end{array}$ & $\begin{array}{c}0.0212^{* * *} \\
(0.000191)\end{array}$ & $\begin{array}{c}0.0272^{* * *} \\
(0.000251)\end{array}$ \\
\hline Log(Age) & $\begin{array}{l}-0.0228^{* * *} \\
(0.00211)\end{array}$ & $\begin{array}{l}-0.0274^{* * *} \\
(0.00221)\end{array}$ & $\begin{array}{l}-0.0288^{* * *} \\
(0.00216)\end{array}$ & $\begin{array}{l}-0.0508^{* * *} \\
(0.00256)\end{array}$ \\
\hline Log(Employment) & $\begin{array}{c}0.322^{* * *} \\
(0.00318)\end{array}$ & $\begin{array}{c}0.403^{* * *} \\
(0.00353)\end{array}$ & $\begin{array}{c}0.354^{* * *} \\
(0.00329)\end{array}$ & $\begin{array}{c}0.474^{* * *} \\
(0.00393)\end{array}$ \\
\hline $\log ^{2}$ (Employment) & $\begin{array}{c}-0.0298^{* * *} \\
(0.000386)\end{array}$ & $\begin{array}{c}-0.0418^{* * *} \\
(0.000463)\end{array}$ & $\begin{array}{c}-0.0370^{* * *} \\
(0.000437)\end{array}$ & $\begin{array}{c}-0.0479^{* * *} \\
(0.000554)\end{array}$ \\
\hline UK ownership dummy & $\begin{array}{c}-0.00646^{* *} \\
(0.00297)\end{array}$ & $\begin{array}{c}0.000542 \\
(0.00355)\end{array}$ & $\begin{array}{l}-0.00111 \\
(0.00386)\end{array}$ & $\begin{array}{c}0.00717 \\
(0.00531)\end{array}$ \\
\hline Herfindahl index & $\begin{array}{l}-0.0619^{* *} \\
(0.0284)\end{array}$ & $\begin{array}{c}-0.0300 \\
(0.0342)\end{array}$ & $\begin{array}{c}0.0368 \\
(0.0292)\end{array}$ & $\begin{array}{c}-0.0172 \\
(0.0376)\end{array}$ \\
\hline Herfindahl index sq. & $\begin{array}{c}0.124^{* * *} \\
(0.0452)\end{array}$ & $\begin{array}{c}0.0564 \\
(0.0565)\end{array}$ & $\begin{array}{l}-0.0611 \\
(0.0455)\end{array}$ & $\begin{array}{c}0.0399 \\
(0.0642)\end{array}$ \\
\hline Pavitt class 1 & $\begin{array}{c}0.130^{* * *} \\
(0.0159)\end{array}$ & $\begin{array}{c}0.106^{* * *} \\
(0.0201)\end{array}$ & $\begin{array}{l}0.0695^{* * *} \\
(0.0244)\end{array}$ & $\begin{array}{c}0.0388 \\
(0.0513)\end{array}$ \\
\hline Pavitt class 2 & $\begin{array}{l}0.0516^{* * *} \\
(0.0159)\end{array}$ & $\begin{array}{c}0.0243 \\
(0.0178)\end{array}$ & $\begin{array}{l}0.0473^{* * *} \\
(0.0122)\end{array}$ & $\begin{array}{c}0.0255 \\
(0.0214)\end{array}$ \\
\hline Pavitt class 3 & $\begin{array}{l}0.0958^{* * *} \\
(0.0150)\end{array}$ & $\begin{array}{c}0.0281^{*} \\
(0.0155)\end{array}$ & $\begin{array}{l}0.0517^{* * *} \\
(0.0137)\end{array}$ & $\begin{array}{l}-0.00788 \\
(0.0227)\end{array}$ \\
\hline Pavitt class 4 & $\begin{array}{l}0.0507^{* * *} \\
(0.0139)\end{array}$ & $\begin{array}{c}0.0174 \\
(0.0160)\end{array}$ & $\begin{array}{l}0.0454^{* * *} \\
(0.0130)\end{array}$ & $\begin{array}{l}0.0421^{* *} \\
(0.0171)\end{array}$ \\
\hline Aver. Real Eff. Exch. Rate & $-0.000771^{* *}$ & -0.000489 & $-0.00254^{* * *}$ & $-0.0121^{* * *}$ \\
\hline
\end{tabular}




\begin{tabular}{|c|c|c|c|c|}
\hline & $(0.000339)$ & $(0.000689)$ & $(0.000546)$ & $(0.000548)$ \\
\hline \multirow[t]{2}{*}{ Crisis dummy } & $-0.0154^{* * *}$ & $-0.0253^{*}$ & $-0.0335^{* * *}$ & $0.0320^{* * *}$ \\
\hline & $(0.00569)$ & $(0.0135)$ & $(0.0104)$ & $(0.0104)$ \\
\hline \multirow[t]{2}{*}{ Log(FTSE-100) } & 0.00565 & 0.0136 & $0.0606^{* * *}$ & $-0.110^{* * *}$ \\
\hline & $(0.00819)$ & $(0.0107)$ & $(0.0116)$ & $(0.0132)$ \\
\hline \multirow[t]{2}{*}{ Multiple subsidy dummy } & 0.00514 & $0.0142^{* * *}$ & $-0.0296^{* * *}$ & $0.114^{* * *}$ \\
\hline & $(0.00351)$ & $(0.00458)$ & $(0.00395)$ & $(0.00681)$ \\
\hline \multirow[t]{2}{*}{ Constant } & $1.330^{* * *}$ & $1.523^{* * *}$ & $0.956^{* * *}$ & $3.387^{* * *}$ \\
\hline & $(0.132)$ & $(0.130)$ & $(0.0789)$ & $(0.119)$ \\
\hline \multirow[t]{2}{*}{ lambda } & $0.0191^{* * *}$ & $0.0273^{* * *}$ & -0.00473 & $0.116^{* * *}$ \\
\hline & $(0.00449)$ & $(0.00541)$ & $(0.00616)$ & $(0.00905)$ \\
\hline Observation & 161829 & 161829 & 161829 & 161829 \\
\hline
\end{tabular}

Categorical class with 0 (zero) subsidy intensity is excluded. Class 1 is consists of firm/year observations where subsidy intensity is greater than zero but less than or equal to the value at the first quartile; Class 2 refers to subsidy intensity between the first-quartile and median values; Class 3 refers to subsidy intensity between the median and third-quartile value; and Class 4 refers to subsidy intensity equal to or greater than the value at the third quartile. 
Table 8: Ordered Heckman estimates for EU subsidy intensity classes: [Dependant variable: Log (Private R\&D intensity + 1)]

\begin{tabular}{|c|c|c|c|c|}
\hline & Class 1 & Class 2 & Class 3 & Class 4 \\
\hline Log (EU subsidy intensity + 1) & $\begin{array}{c}-0.635 \\
(3.672)\end{array}$ & $\begin{array}{l}-18.46^{* * *} \\
(1.925)\end{array}$ & $\begin{array}{l}4.833^{* * *} \\
(0.545)\end{array}$ & $\begin{array}{l}-0.736^{* * *} \\
(0.0470)\end{array}$ \\
\hline Log (Deflated turnover) & $\begin{array}{c}-0.430^{* * *} \\
(0.00266)\end{array}$ & $\begin{array}{c}-0.349^{* * *} \\
(0.00259)\end{array}$ & $\begin{array}{c}-0.486^{* * *} \\
(0.00313)\end{array}$ & $\begin{array}{l}-0.610^{* * *} \\
(0.00346)\end{array}$ \\
\hline Log(Def. turnover sq.) & $\begin{array}{c}0.0216^{* * *} \\
(0.000190)\end{array}$ & $\begin{array}{c}0.0175^{* * *} \\
(0.000194)\end{array}$ & $\begin{array}{c}0.0252^{* * *} \\
(0.000253)\end{array}$ & $\begin{array}{c}0.0321^{* * *} \\
(0.000342)\end{array}$ \\
\hline $\log ($ Age $)$ & $\begin{array}{l}-0.0240^{* * *} \\
(0.00201)\end{array}$ & $\begin{array}{l}-0.0273^{* * *} \\
(0.00217)\end{array}$ & $\begin{array}{l}-0.0421^{* * *} \\
(0.00291)\end{array}$ & $\begin{array}{l}-0.0453^{* * *} \\
(0.00317)\end{array}$ \\
\hline Log(Employment) & $\begin{array}{c}0.349^{* * *} \\
(0.00344)\end{array}$ & $\begin{array}{c}0.288^{* * *} \\
(0.00327)\end{array}$ & $\begin{array}{c}0.460^{* * *} \\
(0.00479)\end{array}$ & $\begin{array}{c}0.613^{* * *} \\
(0.00603)\end{array}$ \\
\hline $\log ^{2}$ (Employment) & $\begin{array}{l}-0.0335^{* * *} \\
(0.000397)\end{array}$ & $\begin{array}{c}-0.0279^{* * *} \\
(0.000413)\end{array}$ & $\begin{array}{l}-0.0461^{* * *} \\
(0.000604)\end{array}$ & $\begin{array}{c}-0.0615^{* * *} \\
(0.000786)\end{array}$ \\
\hline UK ownership dummy & $\begin{array}{l}-0.00428^{*} \\
(0.00260)\end{array}$ & $\begin{array}{l}-0.000629 \\
(0.00334)\end{array}$ & $\begin{array}{c}0.00120 \\
(0.00506)\end{array}$ & $\begin{array}{l}-0.0210^{* * *} \\
(0.00679)\end{array}$ \\
\hline Herfindahl index & $\begin{array}{l}-0.0362 \\
(0.0287)\end{array}$ & $\begin{array}{l}0.0630^{* *} \\
(0.0302)\end{array}$ & $\begin{array}{c}0.588^{* * *} \\
(0.0447)\end{array}$ & $\begin{array}{l}-0.292^{* * *} \\
(0.0433)\end{array}$ \\
\hline Herfindahl index sq. & $\begin{array}{c}0.0790 \\
(0.0509)\end{array}$ & $\begin{array}{c}-0.0471 \\
(0.0440)\end{array}$ & $\begin{array}{l}-0.748^{* * *} \\
(0.0732)\end{array}$ & $\begin{array}{c}0.418^{* * *} \\
(0.0861)\end{array}$ \\
\hline Pavitt class 1 & $\begin{array}{c}-0.0104 \\
(0.0272)\end{array}$ & $\begin{array}{l}0.0369^{* *} \\
(0.0171)\end{array}$ & $\begin{array}{l}-0.0539^{*} \\
(0.0292)\end{array}$ & $\begin{array}{c}0.0795 \\
(0.0822)\end{array}$ \\
\hline Pavitt class2 & $\begin{array}{l}-0.0445^{*} \\
(0.0243)\end{array}$ & $\begin{array}{l}0.0333^{* *} \\
(0.0141)\end{array}$ & $\begin{array}{c}-0.0697^{* * *} \\
(0.0237)\end{array}$ & $\begin{array}{c}-0.00659 \\
(0.0446)\end{array}$ \\
\hline Pavitt class3 & $\begin{array}{c}-0.0129 \\
(0.0235)\end{array}$ & $\begin{array}{l}0.0463^{* * *} \\
(0.0153)\end{array}$ & $\begin{array}{c}-0.00103 \\
(0.0236)\end{array}$ & $\begin{array}{c}0.0270 \\
(0.0437)\end{array}$ \\
\hline Pavitt class4 & $\begin{array}{c}0.0306 \\
(0.0233)\end{array}$ & $\begin{array}{l}0.0726^{* * *} \\
(0.0160)\end{array}$ & $\begin{array}{c}0.0270 \\
(0.0212)\end{array}$ & $\begin{array}{c}0.0244 \\
(0.0306)\end{array}$ \\
\hline Aver. Real Eff. Exch. Rate & $\begin{array}{l}-0.000873^{* *} \\
(0.000361)\end{array}$ & $\begin{array}{c}0.00257^{* * *} \\
(0.000491)\end{array}$ & $\begin{array}{l}-0.00289^{* * *} \\
(0.000540)\end{array}$ & $\begin{array}{l}-0.0249^{* * *} \\
(0.00158)\end{array}$ \\
\hline Crisis dummy & $\begin{array}{c}-0.0140^{*} \\
(0.00741)\end{array}$ & $\begin{array}{c}0.0303^{* * *} \\
(0.00867)\end{array}$ & $\begin{array}{l}0.0358^{* * *} \\
(0.0107)\end{array}$ & $\begin{array}{l}-0.214^{* * *} \\
(0.0316)\end{array}$ \\
\hline Log(FTSE-100) & $\begin{array}{c}0.00699 \\
(0.00843)\end{array}$ & $\begin{array}{l}-0.0542^{* * *} \\
(0.00884)\end{array}$ & $\begin{array}{c}-0.0783^{* * *} \\
(0.0156)\end{array}$ & $\begin{array}{c}-0.0669^{* * *} \\
(0.0152)\end{array}$ \\
\hline Multiple subsidy dummy & $\begin{array}{c}-0.0656^{* * *} \\
(0.0201)\end{array}$ & $\begin{array}{l}-0.123^{* * *} \\
(0.0146)\end{array}$ & $\begin{array}{l}-0.210^{* * *} \\
(0.0230)\end{array}$ & $\begin{array}{l}-0.123^{* * *} \\
(0.0168)\end{array}$ \\
\hline Constant & $\begin{array}{l}1.401^{* * *} \\
(0.0975)\end{array}$ & $\begin{array}{l}1.469^{* * *} \\
(0.0698)\end{array}$ & $\begin{array}{l}2.573^{* * *} \\
(0.135)\end{array}$ & $\begin{array}{l}5.159^{* * *} \\
(0.220)\end{array}$ \\
\hline lambda & $\begin{array}{l}-0.0960^{* * *} \\
(0.00718)\end{array}$ & $\begin{array}{l}-0.0363^{* * *} \\
(0.00548)\end{array}$ & $\begin{array}{c}-0.0969^{* * *} \\
(0.0113)\end{array}$ & $\begin{array}{c}-0.0626^{* * *} \\
(0.0173)\end{array}$ \\
\hline Observation & 161829 & 161829 & 161829 & 161829 \\
\hline
\end{tabular}

So far, we have interpreted the results with respect to the relationship between subsidy and private $R \& D$ effort only. However, our estimation results indicate that private R\&D intensity is also related to wide range of other firm-level, industry-level and macroeconomic variables. Results from the full sample and from the manufacturing sample depict a consistent picture with respect to the effects of these covariates. Whilst turnover (as a proxy for cash flow) has a 
U-shaped relationship with R\&D intensity; age and size (measured by employment headcount) and market concentration all have an inverted-U relationship. In the case of industry-level factors, we observe that private $R \& D$ intensity is consistently higher in Pavitt technology classes $1-3$ compared to the excluded category of unclassified technology class. Finally, private $R \& D$ intensity is lower during the post-crisis period (2008-2012), when the currency experiences real appreciation, and the FTSE-100 index increases. (These findings and their relationships with the existing literature will be discussed later.

\section{Conclusions}

We have investigated the effects of UK and EU subsidies on privately-funded R\&D intensity, using a sample of over 44 thousand UK firms. The sample consists of R\&D-active firms surveyed in at least one year from 1998-2012. The results are obtained from 4 different estimators, with different degrees of control for selection and time-constant fixed effects: (i) pooled OLS without selection correction; (ii) fixed-effect (within-group) estimation without selection correction; (iii) pooled OLS with selection correction; and (iv) fixed-effect estimation with selection correction. We report that UK subsidies are not associated with additionality in privately -funded $R \& D$ intensity in the full sample, and the additionality effect in manufacturing is too small to be economically significant. In contrast, EU subsidy is associated with an additionality effect of $2 \%$ in both samples. Ordered-Heckman estimations of leverage indicate that an increase in UK subsidy intensity (subsidy/total R\&D) is not likely to make a difference to private $R \& D$ effort in any of the subsidy intensity classes demarcated by 4 quartiles of the subsidy intensity of the distribution. However, an increase in EU subsidy 
intensity is associated with leverage in subsidy intensity class 3, which corresponds to intensity values within the $3^{\text {rd }}$ quartile of the distribution.

Estimation results also indicate that private $R \& D$ intensity is related to wide range of other firm-level, industry-level and macroeconomic variables. Results from the full sample and from the manufacturing sample depict a consistent picture with respect to the effects of these covariates. Whilst turnover (as a proxy for cash flow) has a U-shaped relationship with R\&D intensity; age and size (measured by employment headcount) and market concentration all have an inverted-U relationship. In the case of industry-level factors, we observe that private $R \& D$ intensity is consistently higher in Pavitt technology classes $1-3$ compared to the excluded category of unclassified technology class. Finally, private R\&D intensity is lower during the post-crisis period (2008-2012), when the currency experiences real appreciation, and the FTSE100 index increases. 


\section{References}

Aerts K. and T. Schmidt (2008), Two for the price of one? Additionality effects of R\&D subsidies: A comparison between Flanders and Germany, Research Policy 37, 806-822.

Aerts, K. and D. Czarnitzki (2006), The Impact of Public R\&D-Funding in Flanders, IWT Study No. 54, Brussels.

Aghion, P., N. Bloom, R. Blundell, R. Griffith, and P. Howitt. (2005). Competition and Innovation: An Inverted-U Relationship. Quarterly Journal of Economics, 120(5), 701-728.

Almus, M. and D. Czarnitzki (2003), The effects of public R\&D subsidies on firms' innovation activities: the case of Eastern Germany, Journal of Business and Economic Statistics 21(2), 226-236.

Angrist, J.D. (1998), Estimating the labor market impact of voluntary military service using social security data, Econometrica 66, 249-288.

Arrow, K.J. (1962), Economic Welfare and the Allocation of Resources for Invention, in R.R. Nelson (ed.), The Rate and Direction of Inventive Activity: Economic and Social Factors, National Bureau of Economic Research, Conference Series, Princeton: Princeton University Press, 609-625.

Arrow, K.J. (1996), The Economics of Information: An Exposition, Empirica 23(2), 119-128.

Arrow, K.J. (1999), Information and the organization of industry, in: G. Chichilnisky (ed.), Markets, Information, and Uncertainty. Essays in Economic Theory in Honor of Kenneth J. Arrow, Cambridge: Cambridge University Press, pp. 19-25.

Arrow, K.J. and R.C. Lind (1970), Uncertainty and the Evaluation of Public Investment Decisions, American Economic Review, 60, 364-378.

Balasubramanian, N., \& Lee, J. (2008). Firm age and innovation. Industrial and Corporate Change, 17(5), 1019-1047.

Becker, B. and Hall, S.G. (2013) Do R\&D strategies in high-tech sectors differ from those in low-tech sectors? An alternative approach to testing the pooling assumption. Economic Change and Restructuring 46: 183-202.

BIS (Department for Business Innovation and Skills) (2011), Innovation and Research Strategy for Growth, December 2011. Available at: www.bis.gov.uk/assets/BISCore/innovation/docs/I/11-1387innovation-and-research-strategy-for-growth.pdf .

BIS (Department for Business Innovation and Skills) (2014), Estimating the effect of UK direct public support for innovation, BIS Analysis Paper no. 4. https://www.gov.uk/government/uploads/system/uploads/attachment_data/file/369650/bis-14-1168estimating-the-effect-of-uk-direct-public-support-for-innovation-bis-analysis-paper-number-04.pdf

Blank, D.M., Stigler, G.J., 1957. The Demand and Supply of Scientific Personnel. National Bureau of Economic Research, New York.

Brown, J. R., Fazzari, S. M., \& Petersen, B. C. (2009). Financing innovation and growth: Cash flow, external equity, and the 1990s R\&D boom. The Journal of Finance, 64(1), 151-185. 
Busom, I. (2000), An empirical evaluation of the effects of R\&D subsidies, Economics of Innovation and New Technology 9(2), 111-148.

Buxton, A. J. (1975). The process of technical change in UK manufacturing. Applied Economics, 7(1), 53-71.

Cerulli, G. (2010), Modelling and measuring the effect of public subsidies on business R\&D: a critical review of the economic literature, Economic Record 86, 421-449.

Chiburis, R., \& Lokshin, M. (2007). Maximum likelihood and two-step estimation of an ordered-probit selection model. Stata Journal, 7(2), 167-182.

Cohen, W. M., Levin, R. C., \& Mowery, D. C. (1987). Firm Size and R\&D Intensity: A Re-examination. Journal of Industrial Economics, 35(4), 543-65.

Czarnitzki, D. (2006), Research and development in small and medium-sized enterprises: the role of financial constraints and public funding, Scottish Journal of Political Economy 53(3), 335-257.

Czarnitzki, D. and A.A. Toole (2007), Business R\&D and the interplay of R\&D subsidies and product market uncertainty, Review of Industrial Organization 31(3), 169-181.

Czarnitzki, D. and A.A. Toole (2011), Patent Protection, Market Uncertainty, and R\&D Investment, Review of Economics and Statistics 93(1), 147-159.

Czarnitzki, D. and C. Lopes-Bento (2011a), Evaluation of Public R\&D Policies: A Cross- Country Comparison, World Review of Science, Technology and Sustainable Development, forthcoming.

Czarnitzki, D. and C. Lopes-Bento (2011b), Innovation Subsidies: Does the Funding Source Matter for Innovation Intensity and Performance? Empirical Evidence from Germany, ZEW Discussion Paper No. 11-053, Mannheim.

Czarnitzki, D. and C. Lopes-Bento (2012). Value for money? New microeconometric evidence on public R\&D grants in Flanders, ZEW Discussion Papers, No. 12-034, http://nbnresolving.de/urn:nbn:de:bsz:180-madoc-323085

Czarnitzki, D. and G. Licht (2006), Additionality of Public R\&D Grants in a Transition Economy: The Case of Eastern Germany, Economics of Transition 14(1), 101-131.

Czarnitzki, D. and H. Hottenrott (2011), Financial Constraints: Routine versus Cutting Edge R\&D Investment, Journal of Economics and Management Strategy 20(1), 121-157.

Czarnitzki, D. and K. Hussinger (2004), The Link between R\&D Subsidies, R\&D Spending and Technological Performance, ZEW Discussion Paper No. 04-56, Mannheim.

Czarnitzki, D., H. Hottenrott and S. Thorwarth (2011), Industrial Research versus Development Investment: The Implications of Financial Constraints, Cambridge Journal of Economics 35(3), 527544.

David, P.A., B.H. Hall and A.A. Toole (2000), Is public R\&D a complement or substitute forprivate R\&D? A review of the econometric evidence, Research Policy 29(4-5), 497-529.

Dehejia, R.H. and S. Wahba (1999), Causal effects in nonexperimental studies: reevaluating the evaluation of training programs, Journal of the American Statistical Association 94, 1053-1062.

Dixit, A.K. and R.S. Pindyck, Investment under Uncertainty, Princeton Univ. Press, Princeton, NJ. 
Duguet, E. (2004), Are R\&D subsidies a substitute or a complement to privately funded R\&D? Evidence from France using propensity score methods for non-experimental data, Revue d'Economie Politique 114(2), 263-292.

Garcia, A. and P. Mohnen (2010), Impact of government support on R\&D and innovation, UNU-MERIT Working Paper Series 034, United Nations University, Maastricht Economic and social Research and training centre on Innovation and Technology, Maastricht.

García-Quevedo, J. (2004). Do public subsidies complement business R\&D? A meta-analysis of the econometric evidence. Kyklos, 57(1), 87-102.

Gerfin M. and M. Lechner (2002), A Microeconometric Evaluation of Active Labour Market Policy in Switzerland, Economic Journal 112, 845 -893.

González, X., Jaumandreu, J. and Pazó, C. (2005), Barriers to innovation and subsidy effectiveness, RAND Journal of Economics 36(4), 930-949.

Griliches Z. (1990), Patent Statistics as Economic Indicators: A Survey, Journal of Economic Literature XXVIII, 1661-1707.

Griliches, Z. and J. Mairesse (1984), Productivity and R\&D at the firm level, in: R\&D, Patents and Productivity, Griliches Z (ed.). University of Chicago Press: Chicago, IL; 339-374

Hall, B.H. (1990), The impact of corporate restructuring on industrial research and development, Brooking Papers on Economic Activity (1), 85-136.

Hall, B.H. (2002), The financing of Research and Development, Oxford Review of Economic Policy, $18,35-51$.

Hall, B.H. and A. Maffioli (2008), Evaluating the impact of technology development funds in emerging economies: evidence from Latin America, European Journal of Development Research 20(2), 172-198.

Hall, B.H. and J. Lerner (2010), The financing of R\&D and innovation, in: B.H. Hall and N. Rosenberg (eds.), Handbook of the economics of innovation, Vol. 1, Amsterdam: Elsevier, 609- 639.

Hall, B.H. and J. Van Reenen (2000), How effective are fiscal incentives for R\&D? Research Policy $29,449-469$.

Hall, B.K. J. Mairesse, L. Branstetter and B. Crepon (1998). Does cash flow cause investment and R\&D: An exploration using panel data for French, Japanese and United States scientific firms. In D. Audretsch and A. Thurik (eds), Innovation, Industry Evolution and Employment. Cambridge University Press.

Haskel, J., \& Wallis, G. (2013). Public support for innovation, intangible investment and productivity growth in the UK market sector. Economics letters, 119(2), 195-198.

Heckman, J. J., H. Ichimura and P. Todd (1997), Matching as an econometric evaluation estimator: evidence from evaluating a job training program, Review of Economic Studies 64(4), 605-654.

Heckman, J. J., R. J. Lalonde and J. A. Smith (1999), The economics and econometrics of active labour market programs, in: A. Aschenfelter and D. Card (eds.), Handbook of Labour Economics, Amsterdam, 3, 1866-2097.

Heckman, J.J. (1978), 'Dummy Endogenous Variables in a Simultaneous Equation System', Econometrica, 46, 931-59. 
Heckman, J.J., H. Ichimura and P. Todd (1998a), Matching as an econometric evaluation estimator, Review of Economic Studies 65(2), 261-294.

Heckman, J.J., H. Ichimura, J.A. Smith and P. Todd (1998b), Characterizing selection bias using experimental data, Econometrics 66, 1017-1098.

Holland, P.W. (1986), Statistics and Causal Inference, Journal of the American Statistical. Association 81, 945-960.

Huergo, E., \& Jaumandreu, J. (2004). How does probability of innovation change with firm age? Small Business Economics, 22(3-4), 193-207.

Hughes, A., and A. Mina (2012), The UK R\&D Landscape. Enhancing Value Task Force Report. http://www.jbs.cam.ac.uk/fileadmin/user_upload/centre-for-business-research/downloads/specialreports/specialreport-ukr_dlandscape.pdf

Hussinger, K. (2008), R\&D and Subsidies at the Firm Level: An Application of Parametric and SemiParametric Two-Step Selection Models, Journal of Applied Econometrics 23, $729-747$.

Imbens, G.W. (2000), The role of the propensity score in estimating dose-response functions, Biometrika 87, 706-710.

Imbens, G.W. and J.M. Wooldridge (2009), Recent developments in the econometrics of program evaluation, Journal of Economic Literature 47, 5-86.

Jaffe, A.B. (1986), Technological opportunity and spillovers of R\&D: evidence from firm's patent, profits, and market value, American Economic Review 76 (5), 984-1001.

Lach, S. (2002), Do R\&D subsidies stimulate or displace private R\&D? Evidence from Israel, Journal of Industrial Economics 50(4), 369-390.

Lamberton, D. M. (1996), 'Introduction: 'Threatened Wreckage' or New Paradigm?', in Donald M. Lamberton (Ed.), The Economics of Communication and Information, Cheltham UK and Brookfield US: Edward Elgar, pp. xiii-xxviii.

Larosse, J. (2001), Conceptual and Empirical Challenges of Evaluating the Effectiveness of Innovation Policies with 'Behavioural Additionality', Case of IWT R\&D Subsidies, IWTFlanders, Belgium.

Lechner, M. (1999), Earnings and employment effects of continuous off-the-job training in East Germany after reunification, Journal of Business and Economics Statistics 17, 74-90.

Lechner, M. (2000), An evaluation of public sector sponsored continuous vocational training in East Germany, Journal of Human Resources 35, 347-375.

Lechner, M. (2001), Identification and Estimation of Causal Effects of Multiple Treatments under the Conditional Independence Assumption, in M. Lechner and F. Pfeiffer (eds.), Econometric Evaluation of Labour Market Policies, Physica, Heidelberg, 43-58.

Maddala, G.S. (1983), Limited Dependent and Qualitative Variables in Econometrics. Cambridge University Press, Cambridge.

National Audit Office (2013), Research and Development funding for science and technology in the UK: Memorandum for the House of Commons Science and Technology Committee, 
http://www.nao.org.uk/wp-content/uploads/2013/07/Research-and-development-funding-for-scienceand-technology-in-the-UK1.pdf

Nelson, R.R. (1959), The Simple Economics of Basic Scientific Research, Journal of Political Economy 49, 297-306.

OECD (1993), The Proposed Standard Practice for Surveys of Research and Experimental Development - Frascati Manual, Paris.

OECD/Eurostat (2005), Guidelines for Collecting and Interpreting Innovation Data - the Oslo Manual, 3rd edition, Paris.

ONS (2012), Coverage of the Business Enterprise Research \& Development survey, Office of National Statistics, $\quad$ http://www.ons.gov.uk/ons/guide-method/method-quality/specific/business-andenergy/research---development-surveys/information-note--coverage-of-the-business-enterprise-r-dsurvey.pdf

Polder M. and Veldhuizen E. (2012) Innovation and competition in the Netherlands: testing the inverted $\mathrm{U}$ for industries and firms, Journal of Industry, Competition and Trade, 12(1), pp. 67-91.

Rosenbaum, P.R. and D.B. Rubin (1983), The central role of the propensity score observational studies for causal effects, Biometrica 70, 41-55.

Rubin, D.B. (1977), Assignment to treatment group on the basis of covariate, Journal of Educational Statistics 2, 1-26.

Rubin, D.B. (2008), For objective causal inference, design trumps analysis, The Annals of Applied Statistics 2(3), 808-840.

Schumpeter, J. (1942), Capitalism, Socialism and Democracy, Harper and Row, New York. Smith, J.A. and P.E. Todd (2005), Does matching overcome LaLonde's critique of nonexperimental estimators?, Journal of Econometrics 125, 305-353.

Shefer, D., \& Frenkel, A. (2005). R\&D, firm size and innovation: an empirical analysis. Technovation, 25(1), 25-32.

Takalo, T., T. Tanayama and O. Toivanen (2013), Estimating the benefits of targeted R\&D subsidies, Review of Economics and Statistics, 95(1), 255-272.

Tsai, K. H., \& Wang, J. C. (2005). Does R\&D performance decline with firm size?-A re-examination in terms of elasticity. Research Policy, 34(6), 966-976.

Wallsten S.J. (2000), The effects of government-industry R\&D programs on private R\&D: the case Small Business Innovation Research Program, RAND Journal of Economics 31(1), 82-100.

Zúñiga-Vicente, José Ángel, et al. "Assessing the effect of public subsidies on firm R\&D investment: a survey." Journal of Economic Surveys 28.1 (2014): 36-67. 


\section{Appendix}

Table A1: UK subsidy and privately-funded R\&D effort - Manufacturing.

\begin{tabular}{|c|c|c|c|c|}
\hline & (1) & (2) & (3) & (4) \\
\hline UK_sub_dum & $\begin{array}{l}-0.00339 \\
(0.00332)\end{array}$ & $\begin{array}{c}0.00578^{* *} \\
(0.00241)\end{array}$ & $\begin{array}{c}-0.171^{* * *} \\
(0.00827)\end{array}$ & $\begin{array}{l}0.00880^{* * *} \\
(0.00242)\end{array}$ \\
\hline Log (Deflated turnover) & $\begin{array}{l}-0.309^{* * *} \\
(0.0169)\end{array}$ & $\begin{array}{l}-0.391^{\text {*** }} \\
(0.0300)\end{array}$ & $\begin{array}{c}-0.288^{* * *} \\
(0.00192)\end{array}$ & $\begin{array}{l}-0.374^{* * *} \\
(0.0336)\end{array}$ \\
\hline Log(Def. turnover sq.) & $\begin{array}{c}0.0145^{* * *} \\
(0.000920)\end{array}$ & $\begin{array}{c}0.0176^{* * *} \\
(0.00173)\end{array}$ & $\begin{array}{c}0.0134^{* * *} \\
(0.000125)\end{array}$ & $\begin{array}{c}0.0168^{* * *} \\
(0.00196)\end{array}$ \\
\hline Log(Age) & $\begin{array}{c}-0.0604^{* * *} \\
(0.0152)\end{array}$ & $\begin{array}{c}-0.0142 \\
(0.0321)\end{array}$ & $\begin{array}{l}-0.0643^{* * *} \\
(0.00823)\end{array}$ & $\begin{array}{c}-0.0187 \\
(0.0467)\end{array}$ \\
\hline $\log ^{2}$ (Age) & $\begin{array}{l}0.00765^{* * *} \\
(0.00262)\end{array}$ & $\begin{array}{c}0.00648 \\
(0.00610)\end{array}$ & $\begin{array}{l}0.00834^{* * *} \\
(0.00149)\end{array}$ & $\begin{array}{c}0.00913 \\
(0.00887)\end{array}$ \\
\hline Log(Employment) & $\begin{array}{c}0.231^{* * *} \\
(0.0143)\end{array}$ & $\begin{array}{c}0.154^{* * *} \\
(0.0133)\end{array}$ & $\begin{array}{c}0.226^{* * *} \\
(0.00213)\end{array}$ & $\begin{array}{c}0.154^{* * *} \\
(0.0152)\end{array}$ \\
\hline $\log ^{2}$ (Employment) & $\begin{array}{l}-0.0201^{* * *} \\
(0.00147)\end{array}$ & $\begin{array}{l}-0.0123^{* * *} \\
(0.00148)\end{array}$ & $\begin{array}{l}-0.0200^{* * *} \\
(0.000253)\end{array}$ & $\begin{array}{l}-0.0124^{* * *} \\
(0.00172)\end{array}$ \\
\hline UK ownership dummy & $\begin{array}{l}-0.00415^{*} \\
(0.00239)\end{array}$ & $\begin{array}{c}0.0000595 \\
(0.00250)\end{array}$ & $\begin{array}{l}-0.00318^{* *} \\
(0.00147)\end{array}$ & $\begin{array}{c}0.00178 \\
(0.00236)\end{array}$ \\
\hline Herfindahl index & $\begin{array}{c}0.0179 \\
(0.0182)\end{array}$ & $\begin{array}{c}-0.0123 \\
(0.0185)\end{array}$ & $\begin{array}{c}0.0136 \\
(0.0160)\end{array}$ & $\begin{array}{c}-0.00981 \\
(0.0196)\end{array}$ \\
\hline Herfindahl index sq. & $\begin{array}{c}-0.0253 \\
(0.0328)\end{array}$ & $\begin{array}{c}0.00203 \\
(0.0304)\end{array}$ & $\begin{array}{c}-0.00543 \\
(0.0320)\end{array}$ & $\begin{array}{l}-0.00550 \\
(0.0328)\end{array}$ \\
\hline Pavitt class1 & $\begin{array}{l}0.0844^{* * *} \\
(0.0127)\end{array}$ & $\begin{array}{c}0.0227 \\
(0.0269)\end{array}$ & $\begin{array}{c}0.114^{* * *} \\
(0.00974)\end{array}$ & $\begin{array}{l}-0.0115 \\
(0.0185)\end{array}$ \\
\hline Pavitt class2 & $\begin{array}{l}0.0594^{* * *} \\
(0.0114)\end{array}$ & $\begin{array}{c}0.0152 \\
(0.0249)\end{array}$ & $\begin{array}{c}0.0842^{* * *} \\
(0.00935)\end{array}$ & $\begin{array}{c}-0.0106 \\
(0.0148)\end{array}$ \\
\hline Pavitt class3 & $\begin{array}{l}0.0824^{* * *} \\
(0.0108)\end{array}$ & $\begin{array}{c}0.0277 \\
(0.0246)\end{array}$ & $\begin{array}{c}0.100^{* * *} \\
(0.00894)\end{array}$ & $\begin{array}{l}-0.00437 \\
(0.0142)\end{array}$ \\
\hline Pavitt class 4 & $\begin{array}{c}0.0321^{* * *} \\
(0.00951)\end{array}$ & $\begin{array}{c}0.0163 \\
(0.0232)\end{array}$ & $\begin{array}{c}0.0519^{* * *} \\
(0.00892)\end{array}$ & $\begin{array}{l}-0.00890 \\
(0.0108)\end{array}$ \\
\hline Aver. Real Eff. Exch. Rate & $\begin{array}{c}0.000267 \\
(0.000190)\end{array}$ & $\begin{array}{l}0.000420^{* * *} \\
(0.000159)\end{array}$ & $\begin{array}{l}0.000599^{* * *} \\
(0.000187)\end{array}$ & $\begin{array}{l}-0.0000322 \\
(0.000165)\end{array}$ \\
\hline Crisis dummy & $\begin{array}{c}0.0144^{* * *} \\
(0.00362)\end{array}$ & $\begin{array}{l}0.00853^{* * *} \\
(0.00304)\end{array}$ & $\begin{array}{c}0.0191^{* * *} \\
(0.00351)\end{array}$ & $\begin{array}{l}-0.00378 \\
(0.00374)\end{array}$ \\
\hline Log(FTSE-100) & $\begin{array}{l}-0.00449 \\
(0.00447)\end{array}$ & $\begin{array}{l}-0.00547 \\
(0.00407)\end{array}$ & $\begin{array}{c}-0.00368 \\
(0.00422)\end{array}$ & $\begin{array}{l}-0.0112^{* * *} \\
(0.00424)\end{array}$ \\
\hline Multiple subsidy dummy & $\begin{array}{l}0.00497^{* *} \\
(0.00208)\end{array}$ & $\begin{array}{l}0.00605^{* * *} \\
(0.00152)\end{array}$ & $\begin{array}{l}0.00648^{* * *} \\
(0.00164)\end{array}$ & $\begin{array}{l}0.00490^{* * *} \\
(0.00158)\end{array}$ \\
\hline Inverse Mills - UK & & & & $\begin{array}{c}0.0225^{* * *} \\
(0.00447)\end{array}$ \\
\hline Constant & $\begin{array}{c}1.028^{* * *} \\
(0.0585)\end{array}$ & $\begin{array}{l}1.574^{* * *} \\
(0.113)\end{array}$ & $\begin{array}{c}1.096^{* * *} \\
(0.0376)\end{array}$ & $\begin{array}{l}1.603^{* * *} \\
(0.132)\end{array}$ \\
\hline $\begin{array}{l}\text { Observation } \\
\text { lambda }\end{array}$ & 82628 & 82628 & $\begin{array}{l}68091 \\
0.0888\end{array}$ & 68091 \\
\hline sigma & & 0.221 & 0.147 & 0.204 \\
\hline
\end{tabular}

Cluster-robust standard errors are in parentheses. All estimations include 2-digit industry dummies. Time dummies are not included as the crisis dummy, the FTSE-100 and the average effective exchange rates capture time variation. (1) and (2) are pooled OLS and Fixed-effect without selection correction; (3) is pooled OLS with selection correction; and (4) is FE with selection correction. ${ }^{*} p<0.10,{ }^{* *} p<0.05,{ }^{* * *} p<0.01$ 
Table A2: EU subsidy and privately-funded R\&D effort - Manufacturing.

\begin{tabular}{|c|c|c|c|c|}
\hline & (1) & $(2)$ & (3) & (4) \\
\hline EU subsidy dummy & $\begin{array}{l}0.0152^{*} \\
(0.00814)\end{array}$ & $\begin{array}{l}0.0106 \\
(0.00871)\end{array}$ & $\begin{array}{l}-0.0637^{* * *} \\
(0.00930)\end{array}$ & $\begin{array}{l}0.0192^{* *} \\
(0.00805)\end{array}$ \\
\hline Log (Deflated turnover) & $\begin{array}{l}-0.309^{* * *} \\
(0.0169)\end{array}$ & $\begin{array}{l}-0.391^{* * *} \\
(0.0300)\end{array}$ & $\begin{array}{l}-0.289^{* * *} \\
(0.00192)\end{array}$ & $\begin{array}{l}-0.374^{* * *} \\
(0.0336)\end{array}$ \\
\hline Log(Def. turnover sq.) & $\begin{array}{l}0.0146^{* * *} \\
(0.000920)\end{array}$ & $\begin{array}{l}0.0176^{* * *} \\
(0.00173)\end{array}$ & $\begin{array}{l}0.0135^{* * *} \\
(0.000126)\end{array}$ & $\begin{array}{l}0.0167^{* * *} \\
(0.00195)\end{array}$ \\
\hline Log(Age) & $\begin{array}{l}-0.0603^{* * *} \\
(0.0152)\end{array}$ & $\begin{array}{l}-0.0160 \\
(0.0320)\end{array}$ & $\begin{array}{l}-0.0580^{* * *} \\
(0.00821)\end{array}$ & $\begin{array}{l}-0.0101 \\
(0.0461)\end{array}$ \\
\hline $\log ^{2}$ (Age) & $\begin{array}{l}0.00764^{* * *} \\
(0.00262)\end{array}$ & $\begin{array}{l}0.00711 \\
(0.00608)\end{array}$ & $\begin{array}{l}0.00750^{* * *} \\
(0.00148)\end{array}$ & $\begin{array}{l}0.00636 \\
(0.00861)\end{array}$ \\
\hline Log(Employment) & $\begin{array}{l}0.232^{* * *} \\
(0.0143)\end{array}$ & $\begin{array}{l}0.154^{* * *} \\
(0.0133)\end{array}$ & $\begin{array}{l}0.225^{* * *} \\
(0.00214)\end{array}$ & $\begin{array}{l}0.155^{* * *} \\
(0.0152)\end{array}$ \\
\hline $\log ^{2}$ (Employment) & $\begin{array}{l}-0.0201^{* * *} \\
(0.00147)\end{array}$ & $\begin{array}{l}-0.0123^{* * *} \\
(0.00148)\end{array}$ & $\begin{array}{l}-0.0197^{* * *} \\
(0.000253)\end{array}$ & $\begin{array}{l}-0.0124^{* * *} \\
(0.00172)\end{array}$ \\
\hline UK ownership dummy & $\begin{array}{l}-0.00416^{*} \\
(0.00239)\end{array}$ & $\begin{array}{l}0.000000540 \\
(0.00250)\end{array}$ & $\begin{array}{l}-0.00302^{* *} \\
(0.00148)\end{array}$ & $\begin{array}{l}0.00168 \\
(0.00237)\end{array}$ \\
\hline Herfindahl index & $\begin{array}{l}0.0178 \\
(0.0182)\end{array}$ & $\begin{array}{l}-0.0119 \\
(0.0185)\end{array}$ & $\begin{array}{l}0.0193 \\
(0.0161)\end{array}$ & $\begin{array}{l}-0.0103 \\
(0.0197)\end{array}$ \\
\hline Herfindahl index sq. & $\begin{array}{l}-0.0251 \\
(0.0329)\end{array}$ & $\begin{array}{l}0.00253 \\
(0.0304)\end{array}$ & $\begin{array}{l}-0.0163 \\
(0.0324)\end{array}$ & $\begin{array}{l}-0.00479 \\
(0.0329)\end{array}$ \\
\hline Pavitt class 1 & $\begin{array}{l}0.0844^{* * *} \\
(0.0127)\end{array}$ & $\begin{array}{l}0.0219 \\
(0.0268)\end{array}$ & $\begin{array}{l}0.147^{* * *} \\
(0.0104)\end{array}$ & $\begin{array}{l}-0.00450 \\
(0.0184)\end{array}$ \\
\hline Pavitt class 2 & $\begin{array}{l}0.0593^{* * *} \\
(0.0114)\end{array}$ & $\begin{array}{l}0.0144 \\
(0.0249)\end{array}$ & $\begin{array}{l}0.121^{* * *} \\
(0.0101)\end{array}$ & $\begin{array}{l}-0.00597 \\
(0.0147)\end{array}$ \\
\hline Pavitt class 3 & $\begin{array}{l}0.0824^{* * *} \\
(0.0108)\end{array}$ & $\begin{array}{l}0.0268 \\
(0.0246)\end{array}$ & $\begin{array}{l}0.133^{* * *} \\
(0.00945)\end{array}$ & $\begin{array}{l}0.0000838 \\
(0.0141)\end{array}$ \\
\hline Pavitt class 4 & $\begin{array}{l}0.0320^{* * *} \\
(0.00950)\end{array}$ & $\begin{array}{l}0.0155 \\
(0.0232)\end{array}$ & $\begin{array}{l}0.0752^{* * *} \\
(0.00916)\end{array}$ & $\begin{array}{l}-0.00777 \\
(0.0107)\end{array}$ \\
\hline Aver. Real Eff. Exch. Rate & $\begin{array}{l}0.000318^{*} \\
(0.000184)\end{array}$ & $\begin{array}{l}0.000345^{* *} \\
(0.000156)\end{array}$ & $\begin{array}{l}0.000380^{* *} \\
(0.000186)\end{array}$ & $\begin{array}{l}0.00000880 \\
(0.000153)\end{array}$ \\
\hline Crisis dummy & $\begin{array}{l}0.0154^{* * *} \\
(0.00354)\end{array}$ & $\begin{array}{l}0.00662^{* *} \\
(0.00283)\end{array}$ & $\begin{array}{l}0.0142^{* * *} \\
(0.00349)\end{array}$ & $\begin{array}{l}-0.00301 \\
(0.00318)\end{array}$ \\
\hline Log(FTSE-100) & $\begin{array}{l}-0.00430 \\
(0.00447)\end{array}$ & $\begin{array}{l}-0.00660 \\
(0.00402)\end{array}$ & $\begin{array}{l}-0.00318 \\
(0.00422)\end{array}$ & $\begin{array}{l}-0.000953 \\
(0.00446)\end{array}$ \\
\hline Multiple subsidy dummy & $\begin{array}{l}-0.0109 \\
(0.00819)\end{array}$ & $\begin{array}{l}-0.00279 \\
(0.00845)\end{array}$ & $\begin{array}{l}-0.0110 \\
(0.00709)\end{array}$ & $\begin{array}{l}-0.0110 \\
(0.00792)\end{array}$ \\
\hline Inverse Mills - EU & & & & $\begin{array}{l}0.0129^{* * *} \\
(0.00275)\end{array}$ \\
\hline Constant & $\begin{array}{l}1.016^{* * *} \\
(0.0584)\end{array}$ & $\begin{array}{l}1.595^{* * *} \\
(0.113)\end{array}$ & $\begin{array}{l}0.974^{* * *} \\
(0.0368)\end{array}$ & $\begin{array}{l}1.513^{* * *} \\
(0.124)\end{array}$ \\
\hline $\begin{array}{l}\text { Observation } \\
\text { lambda }\end{array}$ & 82628 & 82628 & $\begin{array}{c}68091 \\
0.0474\end{array}$ & 68091 \\
\hline sigma & & 0.220 & 0.143 & 0.204 \\
\hline rho & & 0.744 & 0.330 & 0.740 \\
\hline
\end{tabular}

Cluster-robust standard errors are in parentheses. All estimations include 2-digit industry dummies. Time dummies are not included as the crisis dummy, the FTSE-100 and the average effective exchange rates capture time variation. (1) and (2) are pooled OLS and Fixed-effect without selection correction; (3) is pooled OLS with selection correction; and (4) is FE with selection correction. ${ }^{*} p<0.10,{ }^{* *} p<0.05,{ }^{* * *} p<0.01$ 